University of Rhode Island

DigitalCommons@URI

Civil \& Environmental Engineering Faculty

Publications

Civil \& Environmental Engineering

$9-10-2019$

\title{
Microstructure and Strength Development of Sodium \\ Carbonate-Activated Blast Furnace Slags
}

Busra Akturk

Sumeru Nayak

Sumanta Das

University of Rhode Island, sumanta_das@uri.edu

Ahmet B. Kizilkanat

Follow this and additional works at: https://digitalcommons.uri.edu/cve_facpubs

The University of Rhode Island Faculty have made this article openly available.

Please let us know how Open Access to this research benefits you.

This is a pre-publication author manuscript of the final, published article.

Terms of Use

This article is made available under the terms and conditions applicable towards Open Access Policy Articles, as set forth in our Terms of Use.

\section{Citation/Publisher Attribution}

Akturk, Busra, Nayak, Sumeru, Das, Sumanta, \& Kizilkanat, Ahmet B. (2019). Microstructure and Strength Development of Sodium Carbonate-Activated Blast Furnace Slags. Journal of Materials in Civil Engineering, 31(11), 04019283. https://doi.org/10.1061/(ASCE)MT.1943-5533.0002944

This Article is brought to you for free and open access by the Civil \& Environmental Engineering at DigitalCommons@URI. It has been accepted for inclusion in Civil \& Environmental Engineering Faculty Publications by an authorized administrator of DigitalCommons@URI. For more information, please contact digitalcommonsgroup@uri.edu. 


\title{
Microstructure and Strength Development of Sodium Carbonate-Activated Blast Furnace Slags
}

\author{
Busra AKTURK $^{1}$, Sumeru Nayak ${ }^{2}$, Sumanta Das ${ }^{3}$ and Ahmet B. KIZILKANAT ${ }^{4}$ \\ ${ }^{1}$ Yildiz Technical University, Department of Civil Engineering, Construction Materials Division, Davutpasa \\ Campus, 34220, Istanbul, Turkey, Email: bucar@yildiz.edu.tr \\ ${ }^{2}$ University of Rhode Island, Civil and Environmental Engineering, Kingston, RI 02881, United States, Email: \\ sumeru@uri.edu \\ ${ }^{3}$ University of Rhode Island, Civil and Environmental Engineering, Kingston, RI 02881, United States, Email: \\ sumanta_das@uri.edu \\ ${ }^{4}$ Yildiz Technical University, Department of Civil Engineering, Construction Materials Division, Davutpasa \\ Campus, 34220, Istanbul, Turkey, Email: bkkanat@yildiz.edu.tr (corresponding author)
}

Akturk B., Nayak S., Das S., Kizilkanat A.B., (2019) "Microstructure and Strength Development of Sodium Carbonate Activated Blast Furnace Slags”, Journal of Materials in Civil Engineering ASCE, 31(11): 04019283 .

https://doi.org/10.1061/(ASCE)MT.1943-5533.0002944

\begin{abstract}
This paper presents the study of alkali activated slags where sodium carbonate acts as a primary activator. The slow activation mechanism of sodium carbonate is accelerated by sodium hydroxide and with traces of calcium hydroxide. Strength development and the progress of hydration of the mixes are studied with the phase transformation and development of microstructural features through quantitative techniques such as thermogravimetric analysis and phase-identification techniques such as Fourier transform infrared spectroscopy and X-ray diffraction. Sodium carbonate replacement with sodium hydroxide and the presence of calcium hydroxide in the binder as a replacement of the slag enhances the rate of dissolution of slag leading to a faster strength development. Calcium hydroxide is significantly increased the compressive strength even at early age. On the other hand, sodium hydroxide substitution is effective at later ages of the reaction when used at high dosages (e.g. 40\%). Formation of strength giving phases such as hydrotalcite and calcium aluminum silicate hydrate are confirmed with the microstructure analysis and explains the strength development.
\end{abstract}

Keywords: Alkali activated materials; compressive strength development; microstructure; slag; sodium carbonate. 


\section{INTRODUCTION}

Portland cement (PC) production is responsible for 5-8\% of global $\mathrm{CO}_{2}$ emissions (Scrivener and Kirkpatrick, 2008). Thus, in the past two decades, alkali activated materials (AAM) have gained increased attention as an environment friendly alternative to PC in concrete and are now available in several countries as a commercial cementitious product (van Deventer et al., 2010; Provis and van Deventer, 2014; Provis, 2014). It has been found that the production of AAM leads to 55\%-80\% reduction in $\mathrm{CO}_{2}$ emissions compared to PC (Yang et al., 2013; Duxson et al. 2007) and is less energy intensive when compared to PC production (Abdalqader et al., 2016).

AAM are produced by the dissolution of aluminosilicates from pozzolanic waste materials in alkaline environment which subsequently leads to the precipitation of hydration products (Abdalqader et al., 2016; Shi et al. 2006). There are several factors such as fineness, composition, mineralogy of the precursor used, the type and concentration of the alkali activator, the mixing procedure, and the curing conditions that affect the microstructure of AAM (Ke et al., 2016; Winnefeld et al., 2014). Especially, the type of activator and raw material are two of the most important factors as they determine the fresh and hardened state properties of AAM.

The most common activators used in alkali activation are sodium/potassium hydroxides and sodium silicate as they have the dual effect of raising the $\mathrm{pH}$ as well as facilitating the dissolution (Provis and van Deventer, 2014). However, they have several disadvantages such as they are expensive and are caustic in nature (Ke et al., 2016; Turner and Collins, 2013; Abdalqader et al., 2016). Therefore, naturally available sodium carbonate (NC) is gaining attention as the cost effective and environmentally friendly alternative to synthetic alkali hydroxides and silicates (Ke et al., 2016; Luukkonen et al., 2018). Turkey has the second largest NC reserves with 840 million tons (Marcu et al., 2015) out of the more than 25 billion tons worldwide. Utilization of this great potential in AAM production would contribute to the sustainability. However, NC activators suffer from prolonged setting time and delayed strength development (Ke et al., 2016). It is of vital importance that the $\mathrm{pH}$ level of the solution should be at desired level to facilitate dissolution of the precursor which in turn leads to the formation of calcium aluminum silicate hydrate (C-(A)-S-H) type gels which provide the strength (Huanhani et al., 1993). 
Since the $\mathrm{pH}$ of the NC solution is below 12, the dissolution process is slow (Ke et al., 2016). The slow reaction mechanism of $\mathrm{NC}$-activated slag was explained in different studies. Jimenez and Puertas (2001) reported that the reason of the prolonged stiffening of NC-activated slags is the initial formation of carbonate salts. Bernal et al. (2014) indicated that the $\mathrm{CO}_{3}{ }^{2-}$ ion concentration in the pore solution and the initially precipitated calcium carbonate govern the activation process to a significant extend. It is known that dissolved $\mathrm{Ca}^{2+}$ ions from the slag first react with $\mathrm{CO}_{3}{ }^{2-}$ from $\mathrm{NC}$ solution and generate carbonate salts such as calcite $\left(\mathrm{CaCO}_{3}\right)$ and gaylussite $\left(\mathrm{Na}_{2} \mathrm{Ca}\left(\mathrm{CO}_{3}\right)_{2} .5 \mathrm{H}_{2} \mathrm{O}\right)$ and increase $\mathrm{pH}$ through the release of hydroxide ions. This reaction appears before the precipitation of C-(A)-S-H gel which consumes $\mathrm{Ca}^{2+}$, hinders the increase of $\mathrm{pH}$ and causes dissolution deceleration of silicate species. Therefore, both the hardening and stiffening processes are considerably low due to the lack of $\mathrm{Ca}^{2+}$ ions and the presence of the $\mathrm{CO}_{3}{ }^{2-}$ ions in the system.

In previous studies, acceleration methods of $\mathrm{NC}$-activation mechanism is investigated with different accelerators. Kovtun et al. (2015) reported that NC activation of slag can be accelerated using ordinary PC combined with mixture of silica fume and slaked lime as admixtures. It was also noticed that replacing $\mathrm{NC}$ with sodium hydroxide $(\mathrm{NH})$ increases the $\mathrm{pH}$ further and facilitates faster dissolution of the slag which will result in noticeable acceleration of strength development. Temuujin et al. (2009) observed the improvement in mechanical properties of fly ash based geopolymers cured at room temperature with the addition of calcium compounds. In that study, calcium hydroxide is found to be more effective than calcium oxide and it was reported that calcium compound addition negatively affected the mechanical properties of geopolymer cured at $70^{\circ} \mathrm{C}$. On the other hand, according to Kim et al. (2013) calcium oxide was found to be more effective than calcium hydroxide in activating slag. In another research (Abdalqader et al., 2015), the effect of combining $\mathrm{MgO}$ and $\mathrm{NC}$ on the reaction kinetics of slag/fly ash activation was examined and it was concluded that $\mathrm{MgO}$ incorporation significantly influenced the reaction rate. Increasing the alkali content resulted in an increase of the strength at all ages as well. Alternative accelerators like calcined layered double hydroxides (Ke et. al (2016)), reactive magnesia (Abdalqader et al. (2015)) and reactive $\mathrm{MgO}$ (Jin F. et. al (2015)) are also reported as an effective means of NC activation. Atis et al. (2009) studied the influence of activator type on the strength development of alkali-activated slag mortar and found that NC activated slag mortar exhibited 
comparable setting time and strength with respect to PC mortar. The prolonged formation of sodium calcium carbonate results in a longer setting time for slag activated by NC in contrast to quicker setting systems with sodium silicate activation. NC activation proceeds by pozzolanic reactions that account for compressive strengths similar to PC mortars which increase with Na content.

The studies mentioned above have predominantly focused on the methods to accelerate the reaction kinetics of NC activated slag by either increasing the alkali content or incorporating with reactive admixtures. However, there are very limited research studies which investigate and compare the effect of the alkali concentration and reactive admixtures on the strength development and microstructure analysis of NC activated slag in detail. The aim of the current study is to study the effect of accelerators such as $\mathrm{NH}$, calcium hydroxide and combination of these accelerators on the strength development and microstructure of alkali activated slags cured at ambient temperature.

\section{MATERIALS and METHODS}

\subsection{Materials and Mix Design}

Ground granulated blast furnace slag (GGBS), with a basicity coefficient $\left([\mathrm{CaO}+\mathrm{MgO}] / \mathrm{SiO}_{2}\right)$ of 1.02 and a hydration modulus $\left(\left[\mathrm{CaO}+\mathrm{MgO}+\mathrm{Al}_{2} \mathrm{O}_{3}\right] / \mathrm{SiO}_{2}\right)$ of 1.33 , was supplied by Eregli iron and steel plant, Turkey. Slaked lime $\left(\mathrm{Ca}(\mathrm{OH})_{2}\right)$ was used as carbonate binding agent. The physico-chemical properties of GGBS and slaked lime $(\mathrm{CH})$ are shown in Table 1.

Table 1. Physico-chemical composition of GGBS and CH

\begin{tabular}{lll}
\hline Materials & GGBS & $\mathrm{CH}$ \\
\hline
\end{tabular}




\begin{tabular}{llcc} 
Chemical composition (\%) & $\mathrm{SiO}_{2}$ & 40.6 & 0.8 \\
& $\mathrm{Al}_{2} \mathrm{O}_{3}$ & 12.6 & 0.4 \\
& $\mathrm{Fe}_{2} \mathrm{O}_{3}$ & 1.2 & 1.2 \\
$\mathrm{MgO}$ & 5.8 & 1.3 \\
& $\mathrm{SO}_{3}$ & 0.1 & - \\
& $\mathrm{Na}_{2} \mathrm{O}$ & 0.8 & - \\
$\mathrm{CaO}$ & 35.7 & 69.0 \\
& $\mathrm{~K}_{2} \mathrm{O}$ & 0.7 & 0.13 \\
& $\mathrm{TiO}_{2}$ & 0.7 & $<0.1$ \\
& $\mathrm{Mn}_{2} \mathrm{O}_{3}$ & 0.8 & - \\
& $\mathrm{S}$ & 0.7 & 0.22 \\
& $\mathrm{Cl}(\mathrm{ppm})$ & 187 & 226 \\
\hline LOI $(\%)$ & & 0.13 & 26.03 \\
Specific surface area $\left(\mathrm{cm}^{2} / \mathrm{g}\right)$ & & 5136 & - \\
Specific gravity $\left(\mathrm{g} / \mathrm{cm}^{3}\right)$ & & 2.93 & 2.32 \\
\hline
\end{tabular}

The particle size distribution was determined by laser diffraction and the median particle sizes $\left(\mathrm{d}_{50}\right)$ of GGBS and $\mathrm{CH}$ were found to be $8.0 \mu \mathrm{m}$ and $2.2 \mu \mathrm{m}$ respectively, as shown in Fig. 1.

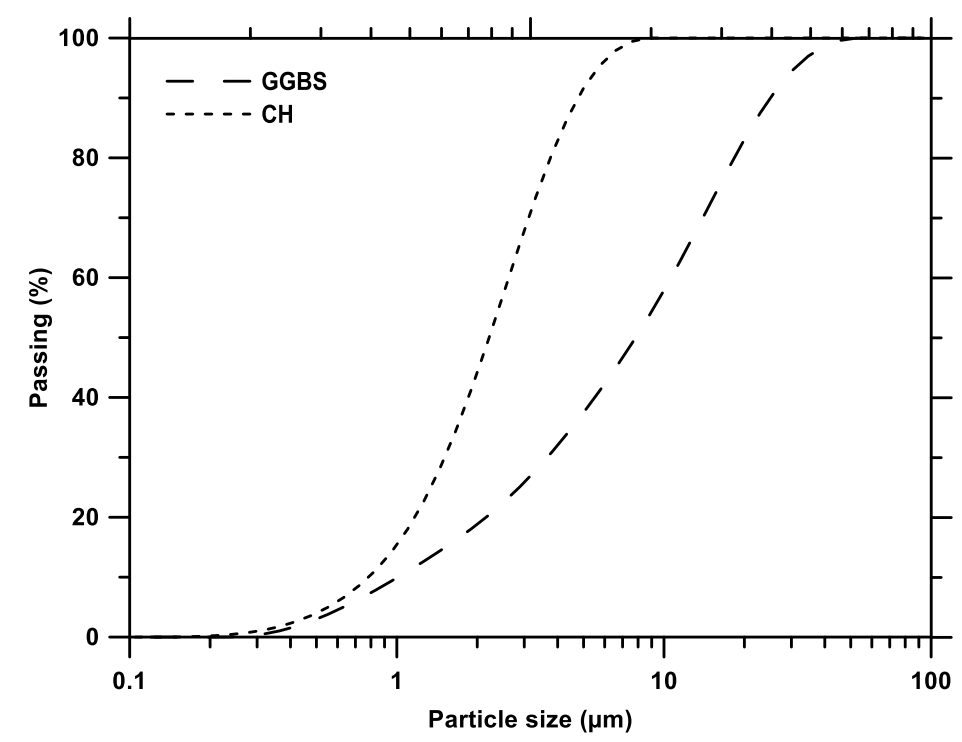

Fig. 1. Particle size distribution of GGBS and $\mathrm{CH}$

Analytical grades of $\mathrm{NC}$ and $\mathrm{NH}$ were used as alkaline activators at $6 \%$ and $10 \%$ by weight of the binder and were prepared by pre-dissolving in tap water. $\mathrm{NC}$ was selected as the primary activator, while NH was used as secondary activator, replaced with NC at $20 \%$ and $40 \%$ by weight of the total activator amount. $\mathrm{CH}$ was used to accelerate the hydration process of the NC-activated slag. The replacement ratio of $\mathrm{CH}$ was chosen as $3 \%$ by weight of slag, which demonstrated the optimum amount to accelerate the stiffening sufficiently among a series of trial mixtures. The water to binder ratio was set as 0.35 and 
0.45 for paste and mortar mixes, respectively. In mortar production, CEN Standard sand was used as aggregate proportioned with a volume of $50 \%$.

Table 2 provides the proportions of the mixes. A total of 12 mixtures were prepared and each mixture was coded as shown in Table 2, where $\mathrm{NC}$ refers to $\mathrm{Na}_{2} \mathrm{CO}_{3}$, the first number refers to $\mathrm{NC}$ percentage in the total activator concentration, the second number refers to total activator amount of mix by weight of the binder and "L" refers to slaked lime.

After the production, all samples were exposed to laboratory conditions $\left(20 \pm 2^{\circ} \mathrm{C}\right.$ and $\left.55 \pm 5 \% \mathrm{RH}\right)$ until the test day.

Table 2. Mix proportions

\begin{tabular}{|c|c|c|c|c|c|}
\hline \multirow[t]{2}{*}{ Mixes } & \multirow{2}{*}{$\begin{array}{c}\text { Activator } \\
\text { concentration }(\%)\end{array}$} & \multicolumn{2}{|c|}{$\begin{array}{l}\text { Binder types and } \\
\text { proportions (\%) }\end{array}$} & \multicolumn{2}{|c|}{$\begin{array}{c}\text { Activator types and } \\
\text { percentages by weight }(\%)\end{array}$} \\
\hline & & GGBS & $\mathrm{Ca}(\mathrm{OH})_{2}$ & $\mathrm{Na}_{2} \mathrm{CO}_{3}$ & $\mathrm{NaOH}$ \\
\hline NC100-6 & & \multirow{6}{*}{100} & \multirow{6}{*}{0} & 100 & 0 \\
\hline NC80-6 & 6 & & & 80 & 20 \\
\hline NC60-6 & & & & 60 & 40 \\
\hline NC100-10 & & & & 100 & 0 \\
\hline NC80-10 & 10 & & & 80 & 20 \\
\hline NC60-10 & & & & 60 & 40 \\
\hline LNC100-6 & & \multirow{6}{*}{97} & \multirow{6}{*}{3} & 100 & 0 \\
\hline LNC80-6 & 6 & & & 80 & 20 \\
\hline LNC60-6 & & & & 60 & 40 \\
\hline LNC100-10 & & & & 100 & 0 \\
\hline LNC80-10 & 10 & & & 80 & 20 \\
\hline LNC60-10 & & & & 60 & 40 \\
\hline
\end{tabular}

\subsection{Methods}

\subsubsection{Compressive strength development}

Compressive strength was determined according to the ASTM C109 (2016). The mortar samples were cast into $50 \mathrm{~mm}$ cubic molds. Afterwards, the molds were covered with a plastic sheet to prevent 
any moisture losses. All specimens were kept in laboratory conditions $\left(20 \pm 2^{\circ} \mathrm{C}\right.$ and $\left.\mathrm{RH} 55 \pm 5 \%\right)$ until the test day. The compressive strength test was carried out at 3, 7, 28 and 90 days and the averages of three repetitions were considered as the compressive strength for each age.

\subsubsection{X-ray diffraction (XRD)}

The XRD analysis was performed at 3,7 and 28 days on powder of the paste samples and the patterns were collected in the range of $5^{\circ}$ to $55^{\circ}(2 \theta)$ with a step size of $0.02^{\circ}(2 \theta)$ and a measuring time of $1 \mathrm{~s} / \mathrm{step}$

\subsubsection{Fourier transform infrared spectroscopy (FTIR)}

In the current study, the FTIR spectra for the reaction products were recorded using a Bruker Tensor 27 FTIR Spectrometer. All spectra were obtained with 32 scans from 4000 to $400 \mathrm{~cm}^{-1}$ per spectrum. The band between 600 and $1800 \mathrm{~cm}^{-1}$ was considered for analyzing the results, since the reaction products were determined at this range. XRD and FTIR analysis were used to describe and assess the hydration products of the paste samples for 3, 7 and 28 days of curing.

\subsubsection{Scanning electron microscopy}

The microstructural analysis of the accompanying paste samples were performed after a 28 day period. Small, broken paste specimens were placed on brass stubs using carbon tape, coated with Au, and then analyzed at an accelerating voltage of $15 \mathrm{kV}$ with a ZEISS EVO LS10 SEM. For examinations by the SEM, secondary electron imaging were used. Atomic ratios were determined using EDS analyses of 80 spots per sample.

\subsubsection{Thermogravimetric analysis}

The reaction products of the NC-activated slag pastes were analyzed by thermogravimetric and derived thermogravimetric analyses (TG-DTG) at the heating rate of $15^{\circ} \mathrm{C} / \mathrm{min}$ from $20^{\circ} \mathrm{C}$ to $900^{\circ} \mathrm{C}$ using a platinum holder and nitrogen as the carrier gas. About 20-25 mg powder of the paste samples were used and TGA-DTG analysis was conducted at the curing age of 28 days. The mass loss at different temperatures was used to quantify the amounts of reaction products.

\section{RESULTS and DISCUSSION}

\subsection{Compressive Strength Development}


Figs. 2 and 3 show the strength development of the GGBS mortars with and without $\mathrm{CH}$ replacement, activated with only $\mathrm{NC}$ and combinations of $\mathrm{NC}+\mathrm{NH}$ solutions with varying ratios. The 3, 7, 28 and 90 days compressive strengths of mixtures range from 0.5 to $20.4 \mathrm{MPa}, 1.2$ to $32.5 \mathrm{MPa}, 3.1$ to $44.4 \mathrm{MPa}$ and 3.4 to 44.5 MPa (Table 3), respectively, which shows that some of these mixes may use in constructions with different strength requirements.

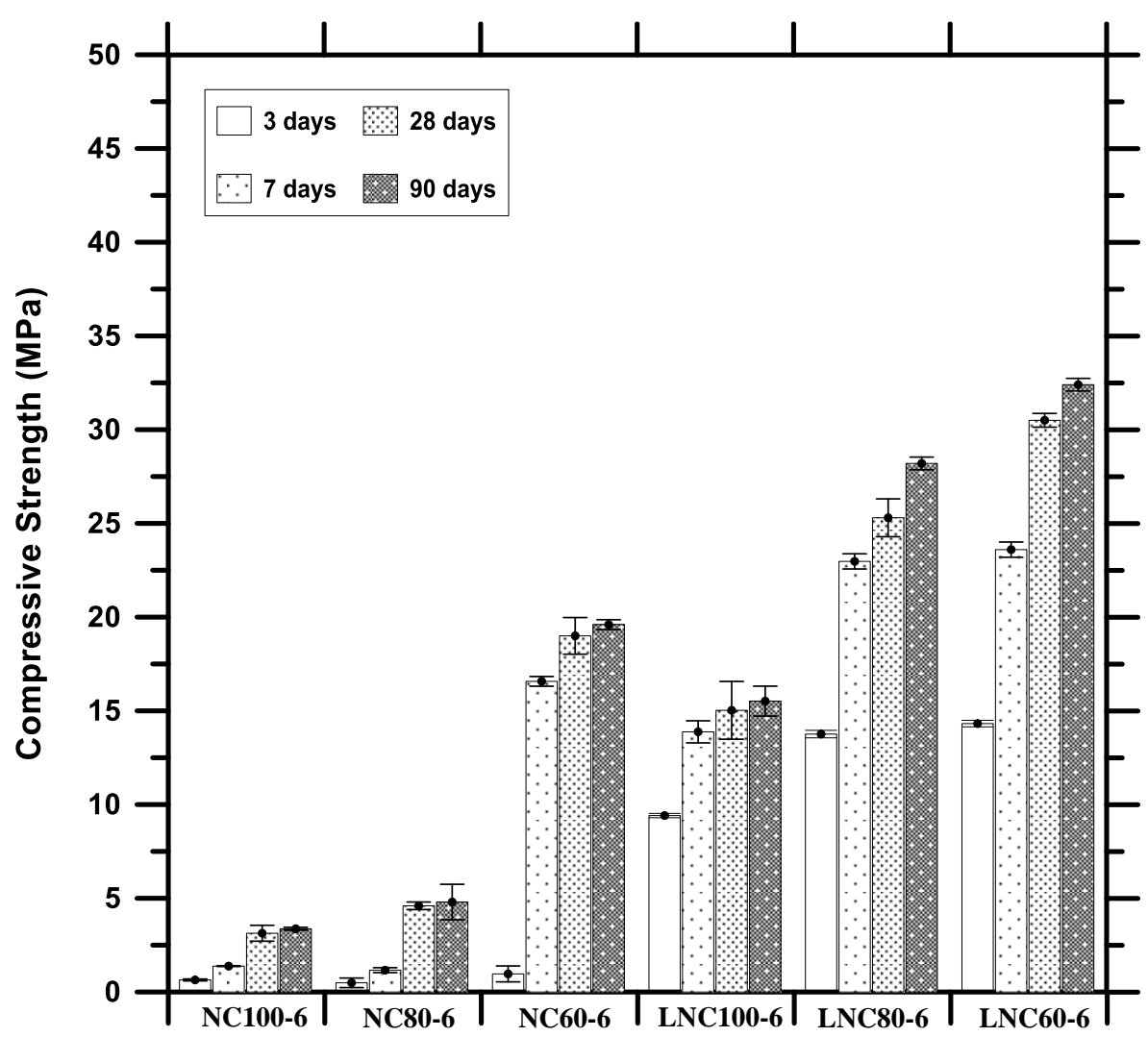

Fig. 2. Compressive strength of NC-6 and LNC-6 mixes 


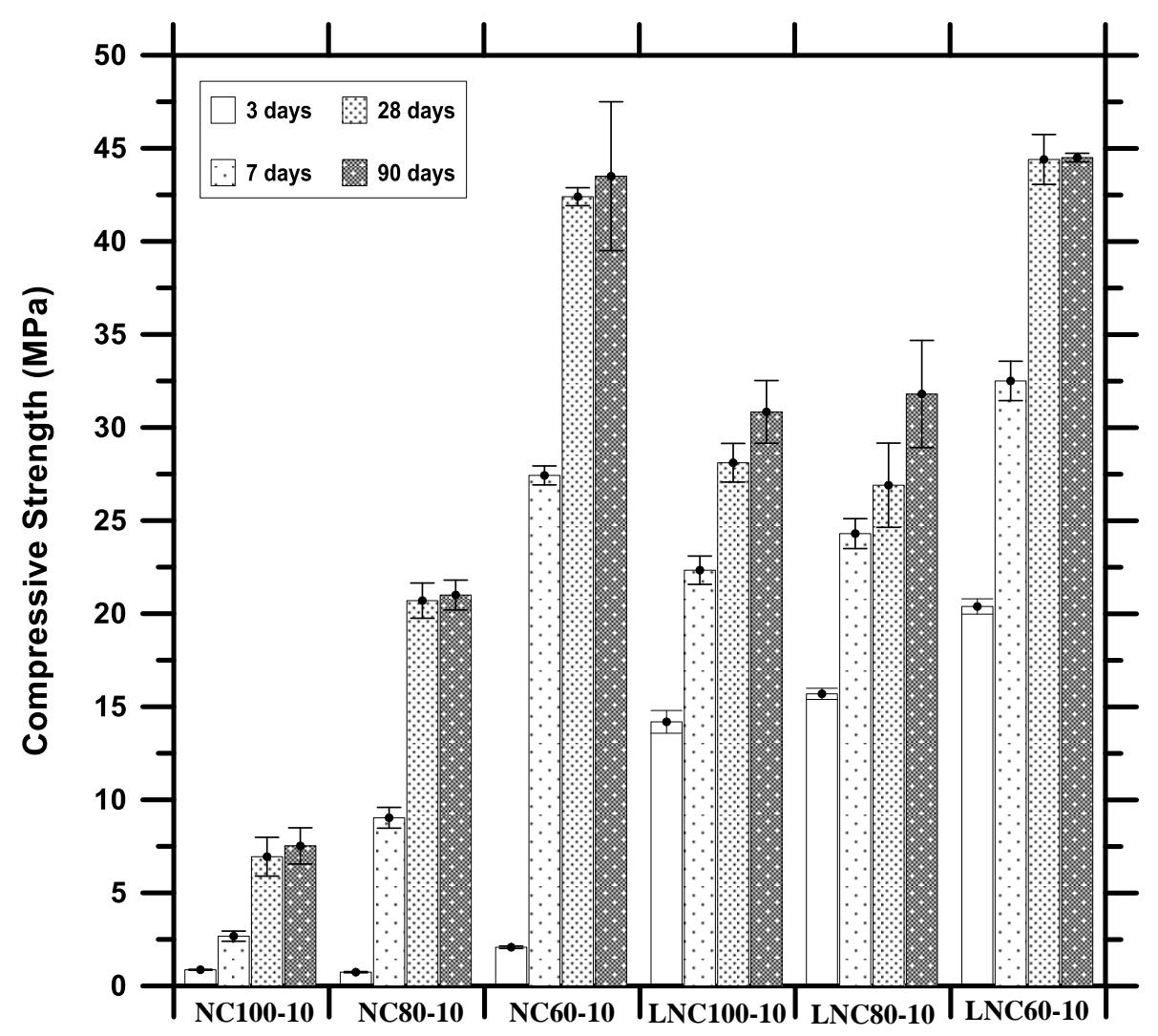

Fig. 3. Compressive strength of NC-10 and LNC-10 mixes

Table 3. Compressive strength results and standard deviation values

\begin{tabular}{lcccc}
\hline \multirow{2}{*}{ Mixes } & \multicolumn{4}{c}{ Compressive strength (MPa) / (Standard deviation) } \\
\cline { 2 - 5 } & 3 days & 7 days & 28 days & 90 days \\
\hline NC100-6 & $0.6(0.1)$ & $1.4(0.3)$ & $3.1(0.4)$ & $3.4(0.1)$ \\
NC80-6 & $0.5(0.0)$ & $1.2(0.1)$ & $4.6(0.2)$ & $4.8(0.9)$ \\
NC60-6 & $1.0(0.0)$ & $16.6(0.3)$ & $19.0(1.0)$ & $19.6(0.3)$ \\
\hline LNC100-6 & $9.4(0.1)$ & $13.9(0.6)$ & $15.0(1.5)$ & $15.5(0.8)$ \\
LNC80-6 & $13.8(0.2)$ & $23.0(0.4)$ & $25.3(1.0)$ & $28.2(0.3)$ \\
LNC60-6 & $14.3(0.2)$ & $23.6(0.4)$ & $30.5(0.4)$ & $32.4(0.3)$ \\
\hline NC100-10 & $0.9(0.0)$ & $2.7(0.3)$ & $6.9(1.0)$ & $7.5(1.0)$ \\
NC80-10 & $0.7(0.0)$ & $9.0(0.6)$ & $20.7(0.9)$ & $21.0(0.8)$ \\
NC60-10 & $2.1(0.1)$ & $27.4(0.5)$ & $42.4(0.5)$ & $43.5(4.0)$ \\
\hline LNC100-10 & $14.2(0.6)$ & $22.3(0.8)$ & $28.1(1.0)$ & $30.8(1.7)$ \\
LNC80-10 & $15.7(0.3)$ & $24.3(0.8)$ & $26.9(2.3)$ & $31.8(2.9)$ \\
LNC60-10 & $20.4(0.4)$ & $32.5(1.1)$ & $44.4(1.3)$ & $44.5(0.2)$ \\
\hline
\end{tabular}

Activation with only NC, for both $6 \%$ and $10 \%$ activator dosages, shows the lowest strength for both the early age and the long term period of curing, in comparison to other mixes (Fig. 2 and 3), which 
confirms the results in (Kovtun et al., 2015). The NC100-6 mixes exhibited hardly any strength throughout the entire curing time. The compressive strength reached only $3.1 \mathrm{MPa}$ at 28 days for this mix (Fig. 2). Increase in activator dosage, from $6 \%$ to $10 \%$, did not cause any change for 3 days, while an increase was seen for further curing ages (Figs. 2 and 3). Recently, the slow activation mechanism of NC-activated slag was explained in detail by Bernal et al. (2014). It was reported that the activation occurred in three steps starting with the dissolution of the ions such as $\mathrm{Ca}, \mathrm{Si}$ and $\mathrm{Al}$ in GGBS and the formation of gaylussite $\left(\mathrm{Na}_{2} \mathrm{Ca}\left(\mathrm{CO}_{3}\right)_{2} \cdot 5 \mathrm{H}_{2} \mathrm{O}\right)$, and zeolite $\mathrm{NaA}\left(\mathrm{Na}_{12} \mathrm{Al}_{12} \mathrm{Si}_{12} \mathrm{O}_{48} \cdot 18 \mathrm{H}_{2} \mathrm{O}\right)$ in the first 24 hours. Then, the reaction might continue with an extended induction period of 4-6 days with the conversion of gaylussite to $\mathrm{CaCO}_{3}$ and the formation of hydrotalcite $\left(\mathrm{Mg}_{6} \mathrm{Al}_{2} \mathrm{CO}_{3}(\mathrm{OH})_{16} \cdot 4 \mathrm{H}_{2} \mathrm{O}\right)$. Finally, the precipitation of C-(A)-S-H gel started. Thus, the reaction mechanism in NC activated slag leads to formation of relatively weaker phases in the initial stages of curing. Consequently, the NC samples fail to develop measurable compressive strengths during the period.

Most of the mixes, almost reach their ultimate strength at 28 days. Only slight improvement was observed at 90 days (Figs. 2 and 3). It can be seen that, there is an increase in the strength-giving phase formation such as hydrotalcite and C-(A)-S-H, from 3 to 7 days, especially for NC-60 mixes, with a related strength increment. Thereafter, the compressive strength increased gradually up to 44 MPa with extended curing.

Substitution of NC with NH did not cause any considerable change in compressive strength at the early age (3 days) for both activator dosages. At further ages, for NC-6 mixes, only a slight increase was seen with $20 \% \mathrm{NH}$ replacement, while with $40 \% \mathrm{NH}$ replacement compressive strength increased substantially for both activator dosages (NC60-6 and NC60-10). Thus, it can be deduced that NH replacement was effective at the further ages of the reaction. Kovtun et al. (2015) studied the acceleration of NC-activated GGBS by replacing NC with $\mathrm{NH}$ at $20 \%$ and $50 \%$ by weight. They found that replacing $\mathrm{NC}$ with $\mathrm{NH}$ at low dosage does not increase the compressive strength at 3 days. On the other hand, for both $\mathrm{NH}$ replacement dosage compressive strength reaches higher values than only NC-activated mixes at 28 days.

Compressive strength increased notably when the $\mathrm{NC}+\mathrm{NH}$ activator dosage was raised to $10 \%$ (Fig. 3). Among the mixes without $\mathrm{CH}$, maximum compressive strength was achieved with NC60-10 mixes 
which reached 2.1 MPa and 43.5 MPa at 3 and 28 days, respectively. Despite the fact that very low early age strength was observed, this mixture exhibited satisfactory compressive strength over time. According to Li and Sun (2000) the compressive strength of $10 \%$ NC activated slag mortar was found as $0 \mathrm{MPa}$ at 3 days and increased up to $60 \mathrm{MPa}$ at 28 days substantiating the combined effect of $\mathrm{NC}$ and $\mathrm{NH}$ being more distinct at later stages. The low early age compressive strength of $\mathrm{NC}$ mixes was due to the lower initial $\mathrm{OH}^{-}$and higher $\mathrm{CO}_{3}{ }^{2-}$ concentration. With the replacement of $\mathrm{NH}$, initial $\mathrm{OH}^{-}$ concentration and the $\mathrm{pH}$ value increase which facilitates the dissolution of the slag and improves the degree of hydration and the strength (Abdalqader et al., 2016; Bernal et al., 2014). On the other hand, lower amount of $\mathrm{CO}_{3}{ }^{2-}$ exists in the medium when $\mathrm{NC}$ replaced by $\mathrm{NH}$. The dissolution of reactive species such as $\mathrm{SiO}_{2}, \mathrm{Al}_{2} \mathrm{O}_{3}$ increases and higher amount of $\mathrm{Ca}^{2+}$ exists in the medium at higher $\mathrm{pH}$ levels. The increased dissolution and reduced $\mathrm{CO}_{3}{ }^{2-}$ concentration provide more calcium to participate in C-A-S-H formation which leads to increase in the compressive strength.

With the inclusion of $\mathrm{CH}$, especially at the early age, significant increase in compressive strength was seen for all mixes irrespective of the NH usage and/or activator concentration (Figs. 2 and 3). This increase was more distinct for LNC80 mixes. For LNC80-6 and LNC80-10 mixes, 3 d compressive strength values were 27 and 22 times higher than those of NC80-6 and NC80-10 mixes, respectively. Only one exception is that NC60-10 mixes reached almost the same strength value with LNC60-10 mixes at 28 and 90 days. These mixes had the maximum compressive strength value with approximately $44 \mathrm{MPa}$ at 28 days among all mixes. Jeong et al. (2015) studied activation of GGBS with using mainly $\mathrm{CH}$ and substituting or adding four different accelerators such as $\mathrm{NH}, \mathrm{NC}, \mathrm{Na}_{2} \mathrm{SO}_{4}$ and $\mathrm{CaSO}_{4} \cdot 2 \mathrm{H}_{2} \mathrm{O}$. They investigated the compressive strength development on paste mixes and concluded that adding NC into the $\mathrm{CH}$ activated mixes gives higher values compared to replacing $\mathrm{CH}$ with $\mathrm{NC}$. It is obvious that $\mathrm{CH}$ plays a significant role in increasing the early and later age compressive strength. The enhanced early alkalinity due to $\mathrm{NaOH}$ generation from $\mathrm{Ca}(\mathrm{OH})_{2}$ and $\mathrm{Na}_{2} \mathrm{CO}_{3}$ (Eq. 1) accelerates slag dissolution (Yuan et al., 2017). However, at later ages $\mathrm{CH}$ replacement is not as effective for higher activator dosages and NH incorporation.

$$
\mathrm{Na}_{2} \mathrm{CO}_{3}+\mathrm{Ca}(\mathrm{OH})_{2} \rightarrow 2 \mathrm{NaOH}+\mathrm{CaCO}_{3}
$$


The increase in compressive strength with $\mathrm{CH}$ can be attributed to a few main reasons: Firstly, dissolved $\mathrm{Ca}^{2+}$ ions from $\mathrm{CH}$ consume the $\mathrm{CO}_{3}{ }^{2-}$ from $\mathrm{NC}$ and form calcite and gaylussite. Removing $\mathrm{CO}_{3}{ }^{2-}$ ions from pore solution increases the $\mathrm{pH}$ thereby facilitating increased ionic dissolution from slag. These dissolved ions $\left(\mathrm{Ca}^{2+}, \mathrm{Si}^{4+}\right.$ and $\left.\mathrm{Al}^{3+}\right)$ lead to increased concentration of reaction products. In addition, $\mathrm{CH}$ introduces higher amount of $\mathrm{Ca}^{2+}$ required for $\mathrm{C}-(\mathrm{A})-\mathrm{S}-\mathrm{H}$ formation and eventually accelerates the reaction of NC-activated slag. Another reason for the high early age strength might be the filling effect of the $\mathrm{CaCO}_{3}$ leading to reduced porosity (Wang et al., 2018).

To understand the strength development mechanism in detail, it is necessary to investigate the timedependent microstructure properties of the NC-activated mixes, including $\mathrm{NC}$ and $\mathrm{NH}$ combinations and also $\mathrm{CH}$ replacement. The following sections are thus focused on the characterization of various aspects of NC-activated GGBS and the effects of the accelerators such as $\mathrm{NH}$ and $\mathrm{CH}$.

\subsection{XRD for Phase-Identification}

Figs. 4-6 show the XRD patterns of the selected $\mathrm{NC} / \mathrm{NC}+\mathrm{NH}$-activated slag pastes at different curing ages such as 3, 7 and 28 days. The selected mixes are NC100-6, NC60-6, NC60-10, LNC100-6 and LNC60-10 which represents the effect of combination of $\mathrm{NC}$ with $\mathrm{NH}$ and replacement of $\mathrm{CH}$ with GGBS. It can be seen from Figs. 4-6, the main reaction products are C-(A)-S-H, hydrotalcite $\left(\mathrm{Mg}_{6} \mathrm{Al}_{2} \mathrm{CO}_{3}(\mathrm{OH})_{16} \cdot 4 \mathrm{H}_{2} \mathrm{O}\right)$, calcite $\left(\mathrm{CaCO}_{3}\right)$ and gaylussite $\left(\mathrm{Na}_{2} \mathrm{Ca}\left(\mathrm{CO}_{3}\right)_{2} \cdot 5 \mathrm{H}_{2} \mathrm{O}\right)$, along with portlandite $\left(\mathrm{Ca}(\mathrm{OH})_{2}\right)$ and dolomite $\left(\mathrm{MgCa}\left(\mathrm{CO}_{3}\right)_{2}\right)$. 


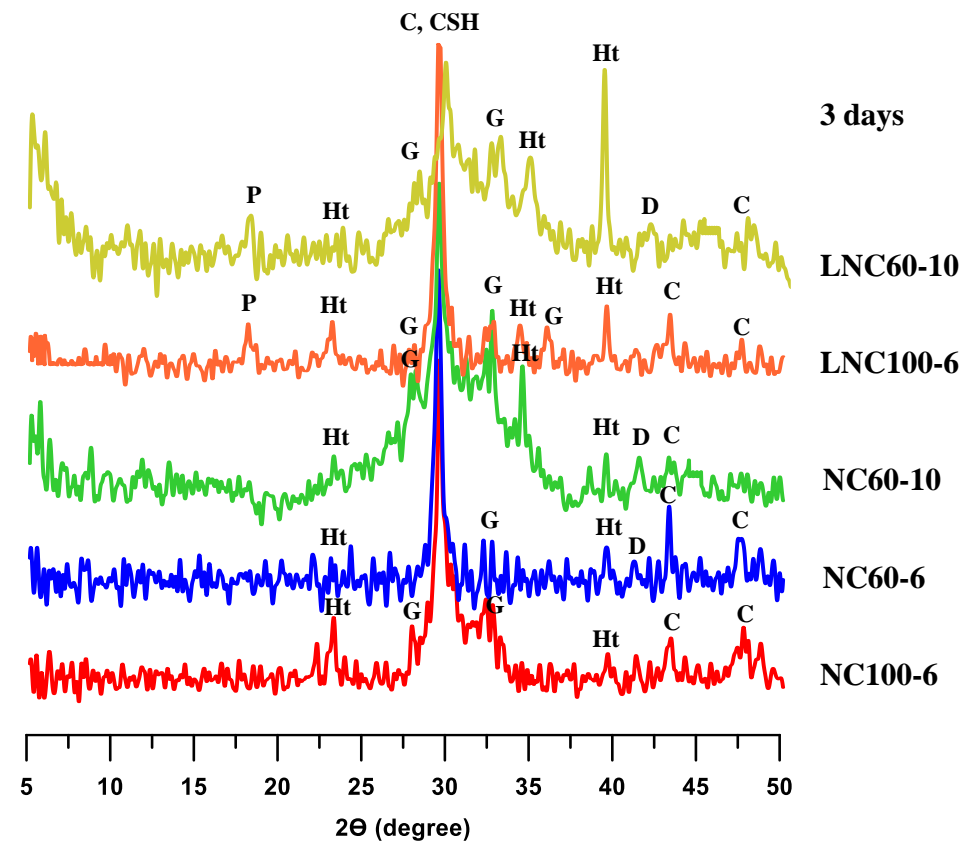

Fig. 4. XRD patterns of selected mixes for 3 days. C: calcite; CSH: calcium alumino silicate hydrate; D: dolomite; G: gaylussite; Ht: hydrotalcite; P: portlandite

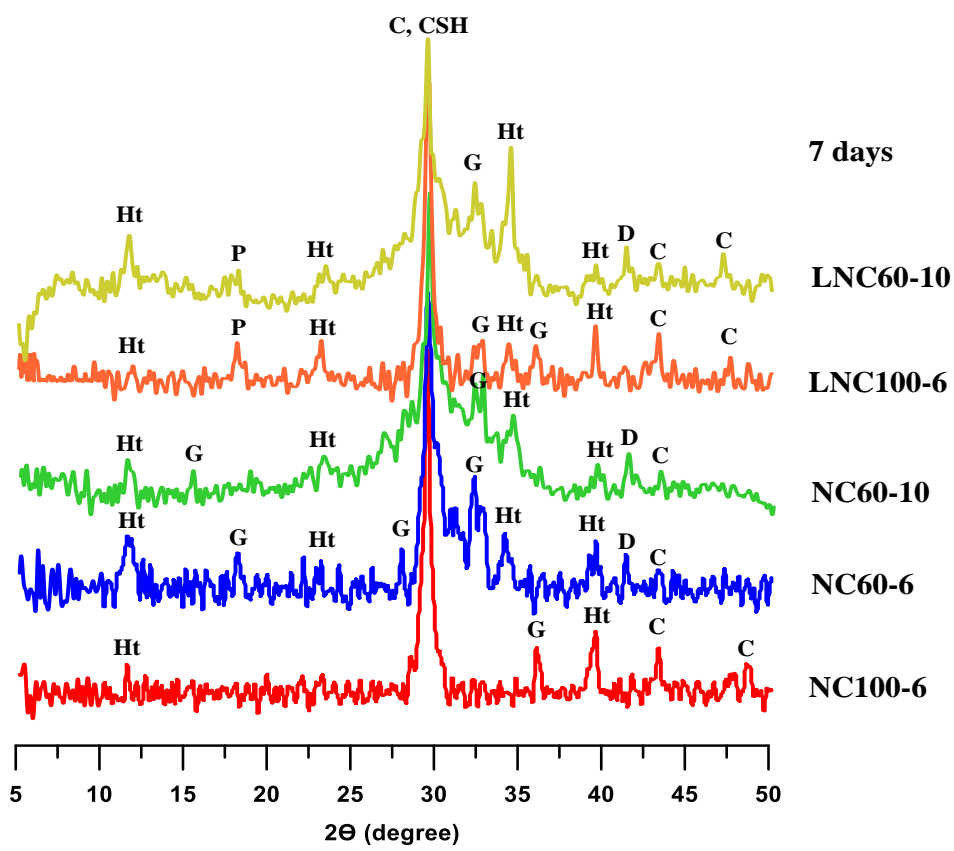

Fig. 5. XRD patterns of selected mixes for 7 days 


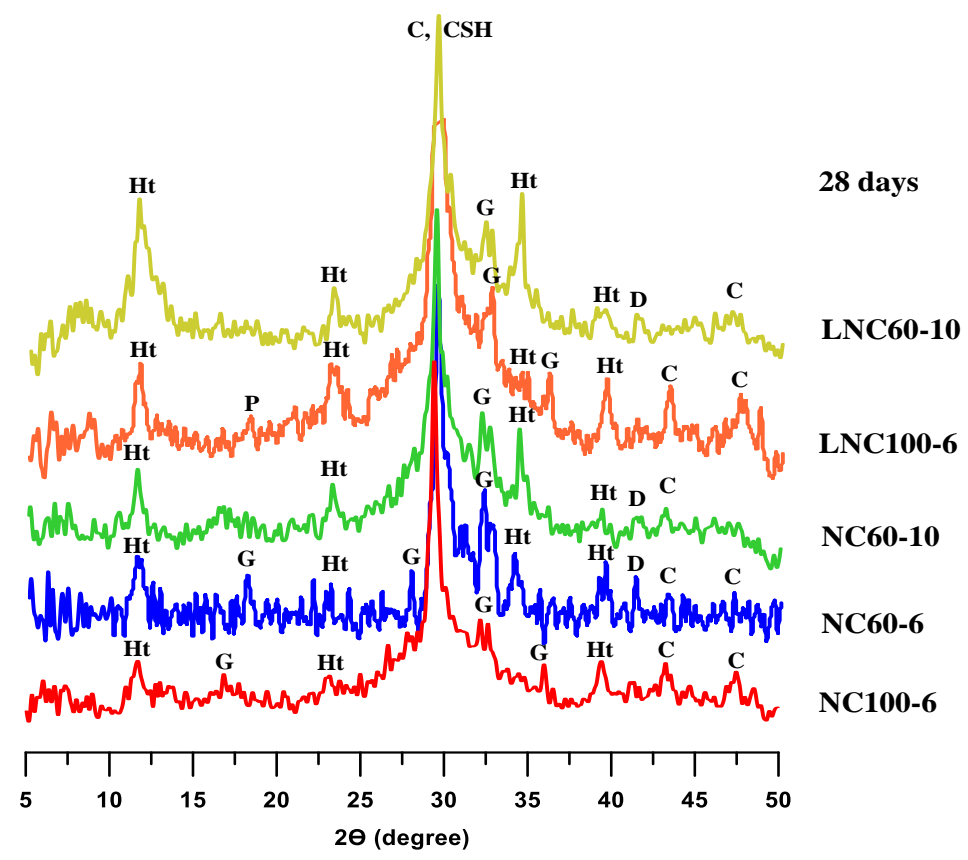

Fig. 6. XRD patterns of selected mixes for 28 days

The main binding phase C-(A)-S-H reflected at approximately $30^{\circ}$ (20) (Rashad et al., 2016; Lopez and Garcia, 2016) was found in all specimens throughout the all XRD measurements. This characteristic peak overlapped with the strong peak for calcite at the same position (Kovtun et al., 2015; Puertas and Carrasco, 2014). In the previous studies, the reason of the overlapping was explained with the semiamorphous nature of the $\mathrm{C}-\mathrm{S}-\mathrm{H}$ and mentioned that this peak appear with the background hump in the $2 \theta$ range of $25^{\circ}-35^{\circ}$ (Gu et al., 2014; Ben Haha et al., 2011, Garcia et al., 2003; Ben Haha et al., 2012). Calcite was also identified at approximately $43^{\circ}(2 \theta)$ and $47^{\circ}(2 \theta)$ for all of the mixes at all curing days, which was due to the cation exchange reaction between slag and $\mathrm{NC}\left(\mathrm{Ca}^{2+}\right.$ from slag and $\mathrm{CO}_{3}{ }^{2-}$ from $\mathrm{NC}$ ), as well as atmospheric carbonation. In $\mathrm{NC100}$ mixes, due to the high concentration of $\mathrm{CO}_{3}{ }^{2-}$ the calcite precipitation occurs at very early stage. Although the addition of $\mathrm{CH}$ was expected to yield enhanced peaks, this assumption was not proved by XRD results (Figs. 4-6). The contradiction can be resolved by considering the formation of gaylussite instead of calcite. The more intensive reflections of gaylussite and hydrotalcite are presented by the incorporation of $\mathrm{CH}$ at the curing age of $3 \mathrm{~d}$ (Fig. 4).

Gaylussite was identified at three different diffraction angles; approximately at $28^{\circ}, 32^{\circ}$ and $36^{\circ}(2 \theta)$ but only the gaylussite peak at $32^{\circ}(2 \theta)$ was seen for all mixes and all curing ages. The number of gaylussite peaks decreased in mixes containing $\mathrm{CH}$, especially after 7 days (Figs. 4-6) since gaylussite converts to more stable products such as calcite and hydrotalcite (Bernal et al., 2014). According to 
Kovtun et al. (2015), the intensity of gaylussite decreased in the pastes produced using with accelerators such as NH and cement.

The characteristic peaks of hydrotalcite was identified at approximately $11.5^{\circ}, 23^{\circ}, 34^{\circ}$ and $39^{\circ}(2 \theta)$, the same diffraction peaks were reported in the previous studies (Bernal et al., 2014; Rashad et al., 2016; Puertas and Carrasco, 2014; Gu et al., 2014). In the $\mathrm{CH}$ blended mixes, the intensities of hydrotalcite was higher than the NC mixes (Figs. 4-6). At the early ages, hydrotalcite was observed only with poor reflections but as a result of the ongoing reactions its intensity increased. A special example; the peak at $11.5^{\circ}(2 \theta)$ was not observed for any of the mixes at 3 days of the reaction but it formed at 7 days and finally its intensity increased for all mixes at 28 days. This increased intensity of hydrotalcite peak might be one of the reason for the strength development from 3 to 7 days.

Diffraction peaks for portlandite $\left(\sim 18^{\circ} 2 \theta\right)$ was only identified in LNC mixes. In LNC60-10 mixes, intensity of the peak was decreased from 3 to 7 days and disappeared at 28 days (Figs. 4-6). On the other hand, in the LNC100-6 mixes portlandite continued to appear at all reaction days, only its intensity decreased. Jeon et al. (2015) reported that $\mathrm{CH}$ turns into the calcite and $\mathrm{CSH}$ at further ages of the reaction in alkali activated systems. The rapid consumption of $\mathrm{CH}$ in LNC60-10 mixes could be due to the formation of $\mathrm{CaCO}_{3}$ from the initial reaction of $\mathrm{CH}$ with $\mathrm{NC}$ and the facilitated $\mathrm{C}-(\mathrm{A})-\mathrm{S}-\mathrm{H}$ formation from the reaction between the $\mathrm{CH}$ and the amorphous phase of the slag (Shi and Day, 2000). This assumption can be supported by the Figs. 2-6. It can be seen that LNC100-6 mixes did not gain a substantial compressive strength increase from 3 to 28 days, while LNC60-10 mixes presented a significant increase during the same period. A longer curing duration, $28 \mathrm{~d}$ (Fig. 6), promotes the development of a more crystalline structure compared with the 3 and 7-day samples (Figs. 4 and 5). Increasing the curing time did not generate new phases, but it increased the crystallinity of C-(A)-S-H type structure, especially in the series of NC60-10 and LNC60-10, visible by sharpening of the main peak at around $\sim 29.5^{\circ}(2 \theta)$ (Bernal et al., 2013).

The XRD test results may explain the compressive strength development of NC-activated slag mortars. At the early age of the reaction (3 days), $\mathrm{NH}$ replacement and activator dosage did not change compressive strength significantly. However, for 7 days and later on, substantial increase was seen. This increment can be explained by the increase in the number and intensity of the peaks such as hydrotalcite 
and C-(A)-S-H. This trend was observed for $\mathrm{CH}$ blended mixes from 3 days. In LNC mixes, the peaks at higher degrees seen in XRD patterns were more intense than NC mixes which resulted in decrease in interlayer distance explaining the gain in compressive strength (Sikander et al., 2017). At 28 days of curing, the intensities of the peaks of main reaction products, calcite/C-(A)-S-H and especially hydrotalcite diffracted at $11.5^{\circ}$ and $23^{\circ}(2 \theta)$, show increased values for all mixes signifying a higher concentration of reaction products thus pointing to higher compressive strength. It is seen from Fig. 2 and 3 that although NC60-10 exhibited lower compressive strength values than LNC60-10 at 3 days, both mixes were presented almost the same values at 28 days. Thus, different XRD diffractograms for 3 days and similar XRD diffractograms for 28 days can be expected for these mixes. At 3 days, while high amount of gaylussite and C-(A)-S-H and moderate amount of hydrotalcite exist for NC60-10; substantially high amount of hydrotalcite and less amount of gaylussite exist for LNC60-10 mixes. Thus, it can be deduced that hydrotalcite, diffracts at approximately $39^{\circ}(2 \theta)$, might have more contribution for compressive strength, compared to other phases. On the other hand, both mixes present the same peaks at the same diffraction angles with similar intensities at 28 days.

\subsection{Evaluation of Chemical Phases of the Binder Using FTIR}

The FTIR spectra of the anhydrous slag used in this experimental study and selected paste samples at 3, 7 and 28 day-age are presented in Figs. 7-10. Although the analysis was conducted between 400 and $4000 \mathrm{~cm}^{-1}$, only the wavelength between 600 and $1800 \mathrm{~cm}^{-1}$ were presented as there is no significant feature beyond this wavelength.

For the anhydrous slag (Fig. 7), the distinct intensity band centered at around $901 \mathrm{~cm}^{-1}$ was related to the asymmetric stretching vibration mode of Si-O-T bonds, where $\mathrm{T}$ represents $\mathrm{Si}$ or $\mathrm{Al}$, and the band position depended on the glass structures of the raw material and another small intense band at approximate $710 \mathrm{~cm}^{-1}$ represents the functional group of $\mathrm{AlO}_{2}$ (Abdalqader et al., 2016; Ben Haha et al., 2011). Moreover, the band at $1423 \mathrm{~cm}^{-1}$ identified in the GGBS is attributed to the symmetric stretching mode of the O-C-O bonds of $\mathrm{CO}_{3}{ }^{2-}$ groups regarded as weathering of the GGBS (Abdalqader et al., 2016). 


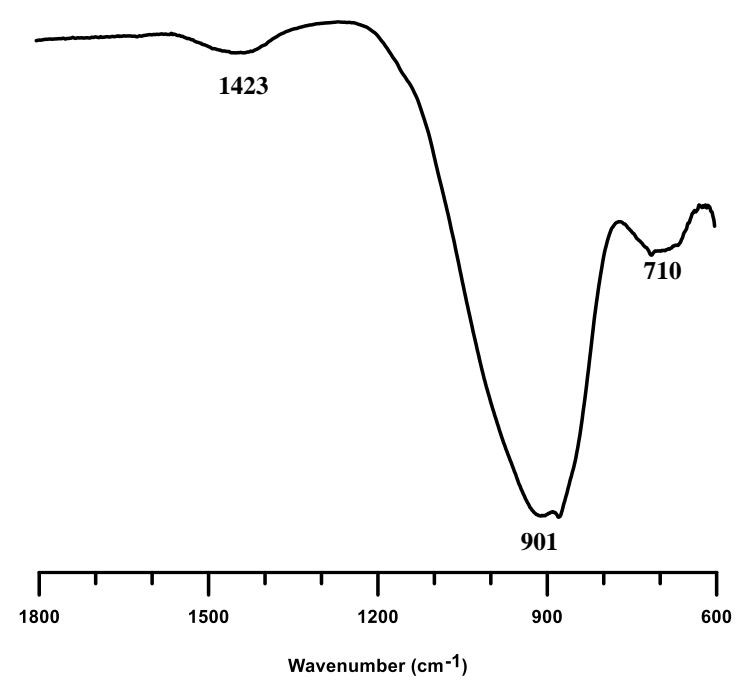

Fig. 7. FTIR spectra of anhydrous slag

NC100-6, NC60-6, NC60-10, LNC100-6 and LNC60-10 mixes were chosen for further analysis, which represents the reaction process and $\mathrm{NH}$ replacement and $\mathrm{CH}$ effect on $\mathrm{NC}$ activated slag. All the paste mixes exhibited similar bands, suggesting similar nature of the hydration products, mainly containing $\mathrm{CO}_{3}{ }^{2-}$ and $\mathrm{C}-(\mathrm{A})-\mathrm{S}-\mathrm{H}$ gel, irrespective of the activator dosage, $\mathrm{NH}$ replacement or inclusion of CH. Major bands were identified at approximately 1430, 945, 870, $665 \mathrm{~cm}^{-1}$ for all mixes (Figs. 810). The band at about $665-712 \mathrm{~cm}^{-1}$ is associated with the stretching vibrations of Al-O bonds in the $\mathrm{AlO}_{4}$ groups which could probably be related to the formation of hydrotalcite and C-(A)-S-H gel (Puertas and Carrasco, 2014).

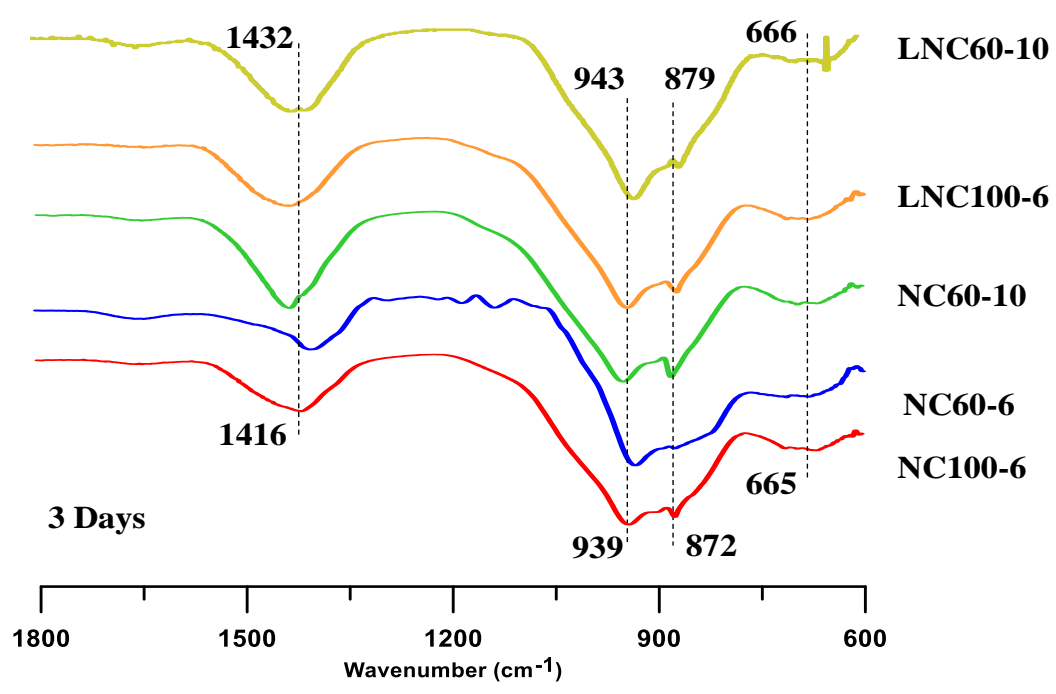

Fig. 8. FTIR spectra of selected mixes at 3 days 


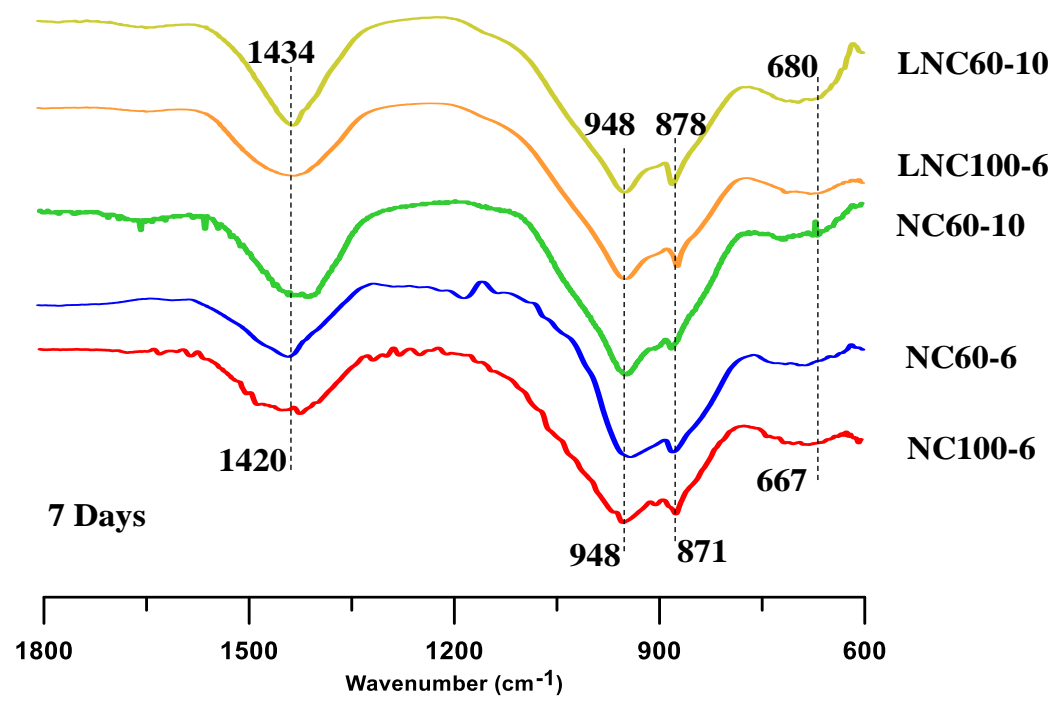

Fig. 9. FTIR spectra of selected mixes at 7 days

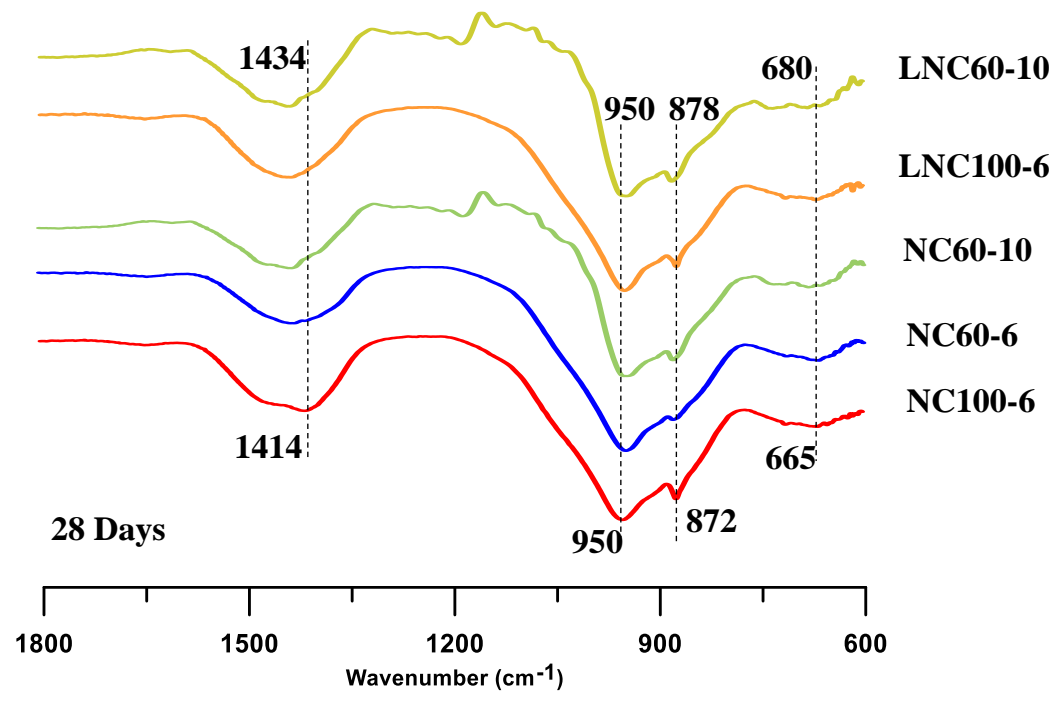

Fig. 10. FTIR spectra of selected mixes at 28 days

The bands at around 1420 and $870 \mathrm{~cm}^{-1}$ suggests the presence of $\mathrm{CO}_{3}{ }^{2-}$, which trace of the presence of gaylussite, calcite, hydrotalcite or dolomite (Puertas and Carrasco, 2014), as detected by both XRD (Figs. 4-6) and TGA (Figs. 17-18). Generally, the vibration of $\mathrm{CO}_{3}{ }^{2-}$ groups is indicated to the activator used (NC). One of the reasons of the reflection at this range may also be due to the carbonation or weathering of the samples.

The main binder gel band, at approximately $945 \mathrm{~cm}^{-1}$, corresponds to the Si-O-T asymmetric stretching bands in the $\mathrm{SiO}_{4}$ tetrahedra (Abdalqader et al., 2016). This finding is in accordance with the formation of C-(A)-S-H of the slag activation, determined by XRD and also confirms in (Garcia et al., 2003; Ben Haha et al., 2012). 
In all mixes, the Si-O-T band shifted slightly towards higher wavenumbers at further ages (Figs. 810). This is possibly due to the ongoing activation of GGBS, which increases the formation of more polymerized gel (Puertas and Jimenez, 2003). Moreover, in the case of pastes accelerated with $\mathrm{CH}$ and with the combination of $\mathrm{CH}$ and $\mathrm{NH}$, the Si-O-T band also shifts towards higher wave numbers of 939 $\mathrm{cm}^{-1}$. This behavior again attributed to the higher degree of polymerization. Abdalqader et al. (2016) reported that replacement of slag with the fly ash causes slight shifting of Si-O-T band to a higher wavenumbers due to activation of fly ash. Since only slight shifting are seen on the Si-O-T band values of mixes, the gel structure of $\mathrm{C}-(\mathrm{A})-\mathrm{S}-\mathrm{H}$ represents only slight differences with the $\mathrm{CH}$ and/or $\mathrm{NH}$ replacement and also activator dosage.

The bands representing $\mathrm{CO}_{3}{ }^{2-}$ ranged between approximately $1410 \mathrm{~cm}^{-1}$ and $1464 \mathrm{~cm}^{-1}$. In the presence of $\mathrm{NH}$ and/or $\mathrm{CH}$ replacement, this band observed at higher wavenumbers, which representing the stronger bonds (Figs. 8-10) and might be indicating higher compressive strength.

\subsection{Microstructural Characterization}

The selected SEM images of the mixes cured for 28 days are shown in Figs. 11-13, and the EDS quantifications of the atomic ratios are given in Table 4.

Higher amount of the micro cracks which negatively affect the strength are seen on the matrix phase of NC mixes compared to LNC mixes (Fig. 11).
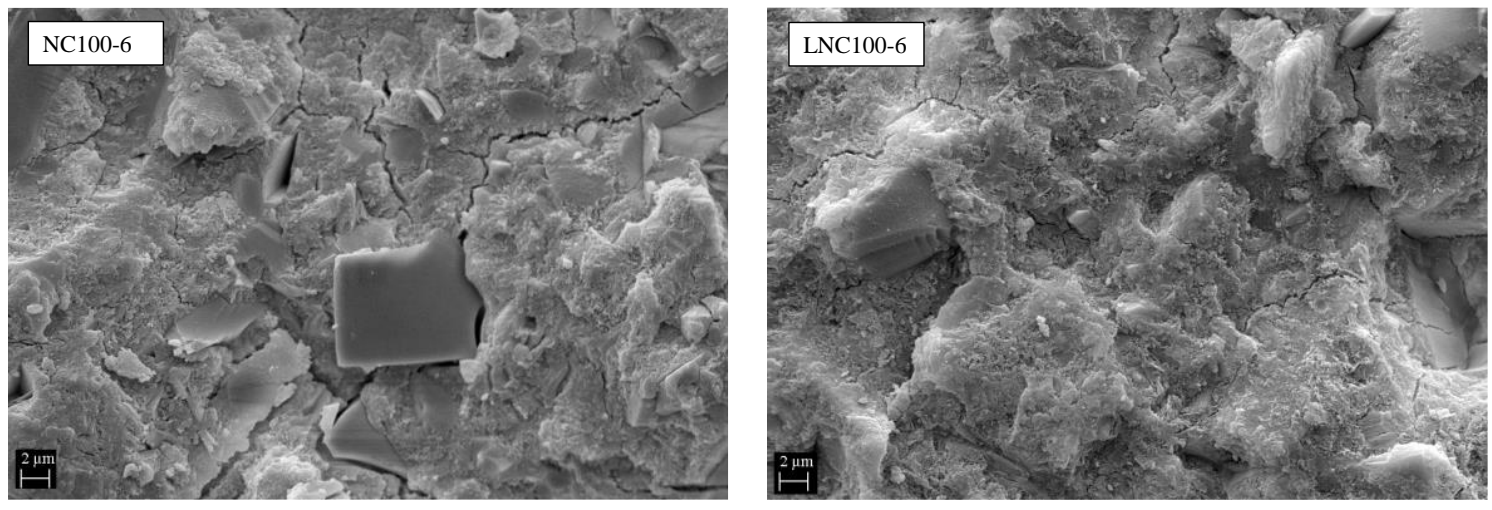

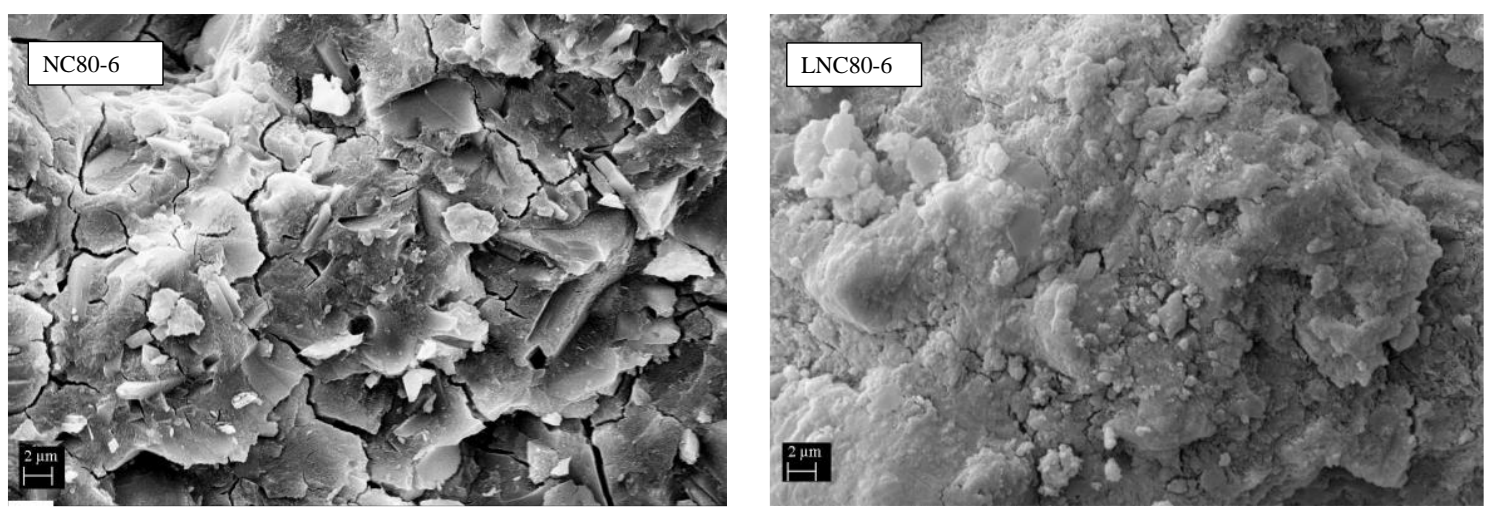

Fig. 11. Comparison of NC and LNC mixes in terms of crack patterns

Micro pores and sharp edges particles were mostly seen in NC100-10 mixes compared to NC60-10

(Fig. 12). Similar findings were reported, in which the matrices looked rather dense with increasing NH concentration (Mustafa et al., 2011). This is attributed to the formation of higher amounts of C-(A)-S-

H gels caused by the increase in pH of pore solution (Jim et al., 2015; Gebregziabiher et al., 2015).
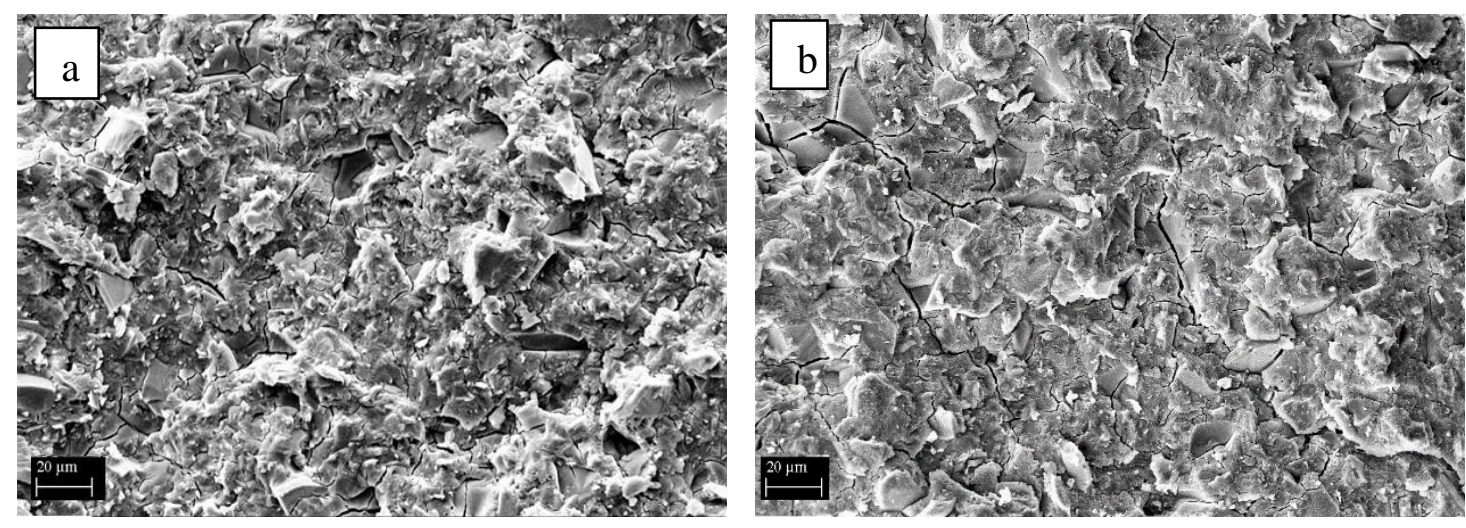

Fig. 12. Comparison of (a) NC100-10 and (b) NC60-10 mixes

Deposition of high amount of calcium carbonates were observed with various sizes (Fig. 13) in all mixes, especially for LNC ones. They are seen on the surface of the slag particles and C-(A)-S-H gel. The filling effect of the calcite may also contributed to the denser microstructure of matrix.
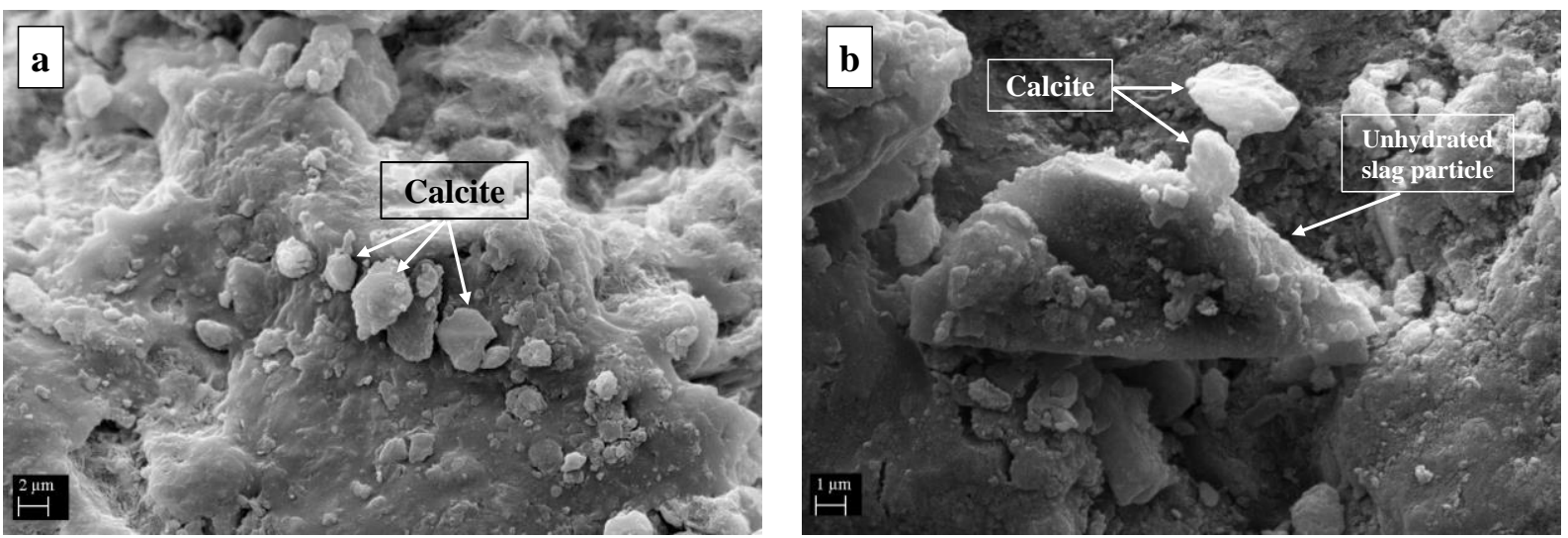
Fig. 13. Depositions of calcium carbonates (a) LNC80-6 and (b) LNC60-6 mixes

Combined with SEM, X-ray microanalysis (EDS) was performed to determine the differences in the elemental composition of the hydrated phases. Difference of various atomic ratios between NC and LNC mixes changes with the activator dosage and $\mathrm{NH}$ replacements and designate different hydration products. The results showed that the major elements were $\mathrm{Ca}, \mathrm{Na}$ and $\mathrm{Si}$ and the minor elements were $\mathrm{Al}$ and $\mathrm{Mg}$ (Table 4). The major elements were mainly attributed to the formation of $\mathrm{C}-(\mathrm{A})-\mathrm{S}-\mathrm{H}$ and also gaylussite and the minor elements were assigned to the hydrotalcite, which was proved by the XRD and FTIR results.

The $\mathrm{Ca} / \mathrm{Si}$ ratios of all pastes were in the range of $0.80-1.38$. LNC mixes has higher $\mathrm{Ca} / \mathrm{Si}$ ratios compared to NC ones, which should be caused by the inclusion of $\mathrm{CH}$. The increase of $\mathrm{Ca} / \mathrm{Si}$ ratio is also seen with the replacement of $\mathrm{NH}$, and that is attributed to the increased $\mathrm{Ca}^{2+}$ ions dissolved from GGBS and hence higher amount of $\mathrm{Ca}^{2+}$ ion occupied in $\mathrm{C}-(\mathrm{A})-\mathrm{S}-\mathrm{H}$ gel. The maximum $\mathrm{Ca} / \mathrm{Si}$ ratios were 0.96 and 1.38 in $6 \%$ and $10 \%$ mixes, respectively. The higher activator dosage resulted in the higher $\mathrm{Ca} / \mathrm{Si}$ ratio, which could lead to increased $\mathrm{Ca}^{2+}$ ion dissolution from the slag in the higher alkaline environment. Higher $\mathrm{Ca} / \mathrm{Si}$ is indicative of the formation of denser, calcium rich products with increased activator (Jin et al., 2015) and $\mathrm{CH}$ inclusion, which was consistent with the compressive strength development. The $\mathrm{Ca} / \mathrm{Si}$ ratio of $\mathrm{C}-\mathrm{S}-\mathrm{H}$ gel depends on the type of activator, curing condition and chemical composition of slag and ranges from 0.6 to 2.3 (Ben Haha et al., 2011; Richardson et al., 2010; Wang and Scrivener, 2003; Lloyd et al., 2010). The Al/Si ratio did not change significantly with changes in activator concentration and $\mathrm{NH}$ and $\mathrm{CH}$ replacement, for all mixes the ratio ranged between 0.290.36. Lloyd et al. (2010) announced that the more $\mathrm{Al}$ incorporated in the gel structure with increasing the activator concentration. Wang and Scrivener (2003) reported that actual Al/Si ratios were in the range between 0.16 and 0.22 depending on activator type and age.

The $\mathrm{Ca} / \mathrm{Na}$ ratios of all pastes were in the range of $2.00-4.75$. The values were higher in LNC mixes compared to NC ones and were lower for $10 \%$ activator concentration. These results are expected to be considering LNC mixes which contains $\mathrm{CH}$ and higher amount of $\mathrm{Ca}^{2+}$ and mixes contain $10 \%$ activator dosage which provides higher amount of $\mathrm{Na}^{2+}$ into the mixes. Na is defined in (Al Bakri et al., 2011; Jin et al., 2015; Gebregziabiher et al., 2015) as charge-balancer for negatively charged Al-O-Si monomers 
in the formation of C/N-A-S-H. Magnesium and part of aluminum can be referred to the hydrotalcite which was found in all mixes by XRD analysis.

Table 4. Average atomic ratios

\begin{tabular}{lccc}
\hline Mixes & $\mathrm{Ca} / \mathrm{Si}$ & $\mathrm{Ca} / \mathrm{Na}$ & $\mathrm{Al} / \mathrm{Si}$ \\
\hline NC100-6 & 0.86 & 3.00 & 0.32 \\
NC80-6 & 0.93 & 3.13 & 0.33 \\
NC60-6 & 0.93 & 2.78 & 0.33 \\
\hline LNC100-6 & 1.08 & 4.00 & 0.31 \\
LNC80-6 & 1.11 & 4.75 & 0.32 \\
LNC60-6 & 1.18 & 4.13 & 0.36 \\
\hline NC100-10 & 0.80 & 2.00 & 0.32 \\
NC80-10 & 0.80 & 2.00 & 0.32 \\
NC60-10 & 0.96 & 2.54 & 0.31 \\
\hline LNC100-10 & 0.96 & 2.30 & 0.29 \\
LNC80-10 & 1.29 & 3.44 & 0.29 \\
LNC60-10 & 1.38 & 2.78 & 0.29 \\
\hline
\end{tabular}

\subsection{Thermogravimetric analysis}

Figs. 14 and 15 depict the representative TGA and DTG results for selected mixes at the curing age of 28 days. All mixes possess similar patterns which shows one main and three small peaks. Mass loss below $200^{\circ} \mathrm{C}$ was caused by the evaporation of free water and partly by the dehydration of C-(A)-S-H gel (Gebregziabiher et al., 2015; Yusuf et al., 2014) and gaylussite (Johnson and Robb, 1973). The peak between $250^{\circ} \mathrm{C}$ and $400^{\circ} \mathrm{C}$ attributed to the decomposition of hydrotalcite (Gu et al., 2014; Richardson et al., 2010), which agrees well with the XRD results. The decomposition of hydrotalcite is generally categorized in three stages (Rashad et al., 2016; Wang and Scrivener, 2003; Lloyd et al., 2010): firstly evaporation of interlayer water under $200^{\circ} \mathrm{C}$; secondly, decomposition of structural hydroxyl groups around $350^{\circ} \mathrm{C}$ and finally decomposition of interlayer carbonate ions around $440^{\circ} \mathrm{C}$. The second decomposition peak around $300^{\circ} \mathrm{C}$ (Fig.15) can be attributed to the dehydroxylation of brucite-like layers of hydrotalcite and the small shoulder at $400-560^{\circ} \mathrm{C}$ could be the decarbonation of hydrotalcite. LNC-10 mixes exhibited an additional tiny peak for $\mathrm{Ca}(\mathrm{OH})_{2}$ decomposition between $400^{\circ} \mathrm{C}$ and $450^{\circ} \mathrm{C}$ 
which agrees well with the results of Kim et al. (2013). This peak was more distinct in LNC60-10 among all LNC-10 mixes (Fig. 15).

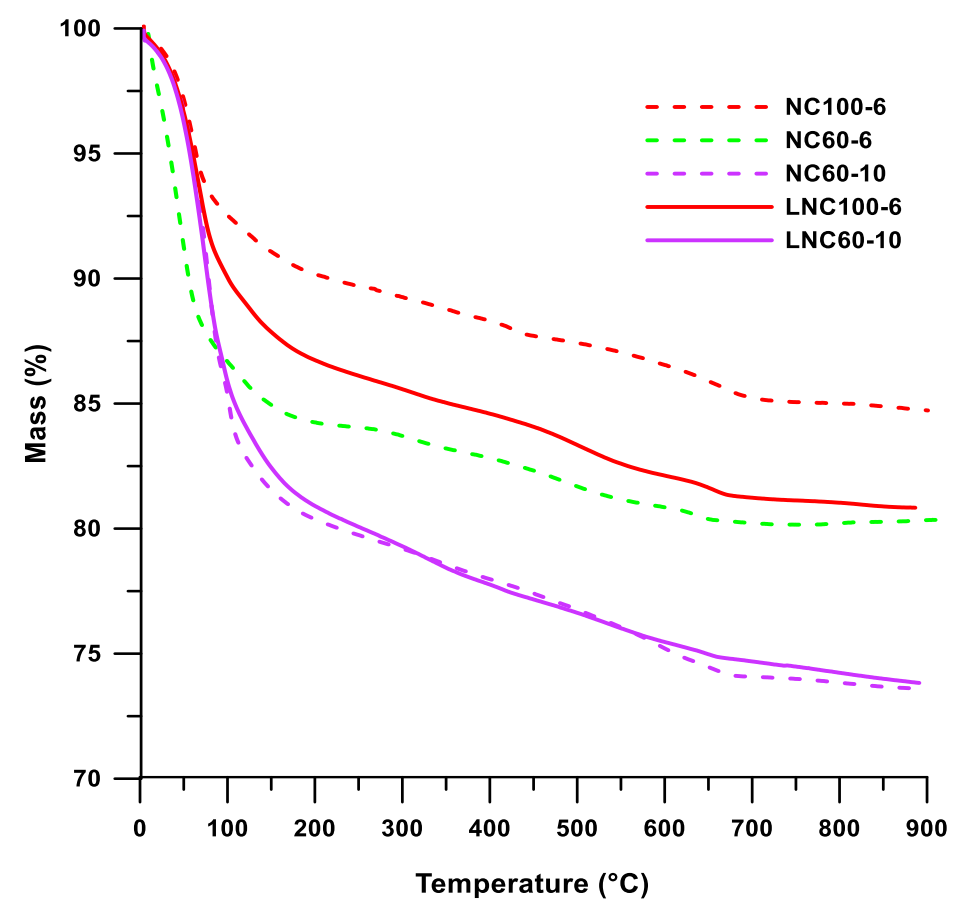

Fig. 14. TGA curves of selected mixes

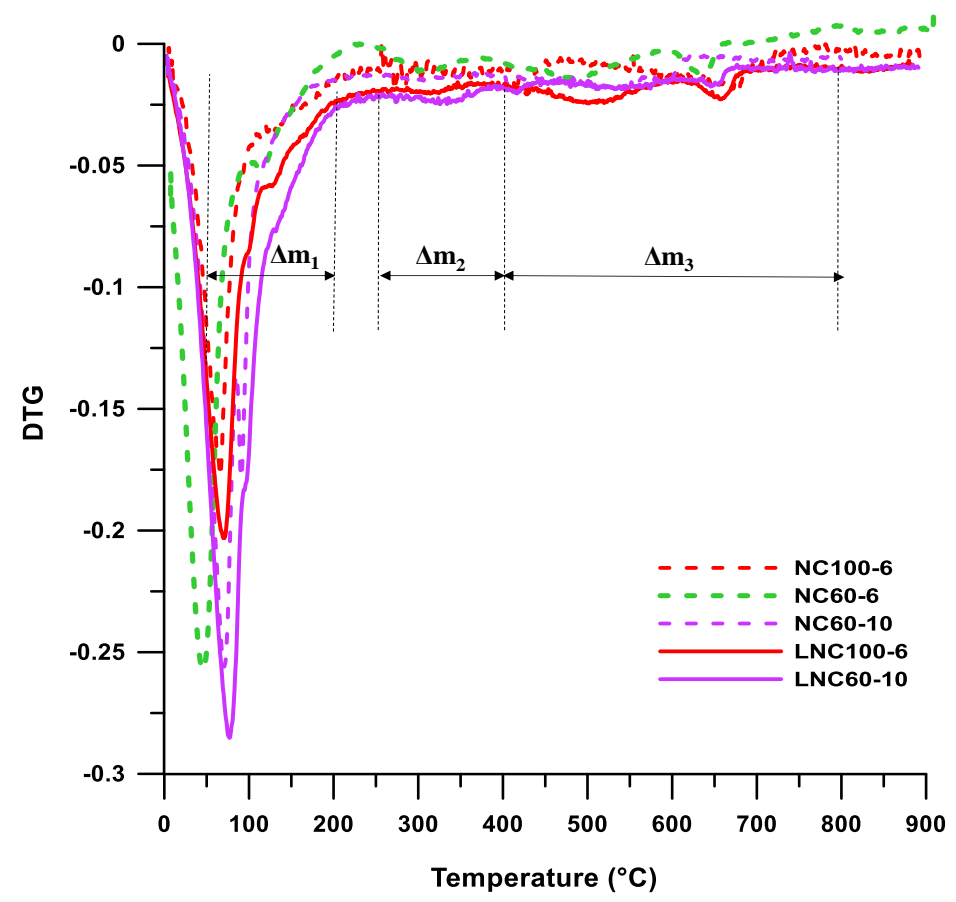

Fig. 15. DTG curves of selected mixes

The mass loss occurred at the temperatures between $400^{\circ} \mathrm{C}$ and $600^{\circ} \mathrm{C}$ can be defined as the decomposition of poorly crystalline $\mathrm{CaCO}_{3}$ (Temuujin et al., 2009; Puertas et al., 2002) or magnesium silicate hydrates (M-S-H) (Abdalqader et al., 2016). Since M-S-H was not observed from the XRD and 
the existence of $\mathrm{CaCO}_{3}$ was proved by the both XRD and SEM, it can be deduced that the mass loss at the temperature range of $400-600^{\circ} \mathrm{C}$ caused by the decomposition of poorly crystalline $\mathrm{CaCO}_{3}$. The decomposition of the carbonate containing phases occurred between $600-800^{\circ} \mathrm{C}$, including calcite (Dweck et al., 2002), gaylussite (Johnson and Robb, 1973) and hydrotalcite (Parashar et al., 2012). Gaylussite thermal behavior consists of three main features: (1) Dehydration up to $250^{\circ} \mathrm{C}$; (2) Crystal transformations between $250^{\circ} \mathrm{C}$ and $500^{\circ} \mathrm{C}$; and (3) Melting and carbonate decomposition from $500^{\circ} \mathrm{C}$ to a maximum of $1050^{\circ} \mathrm{C}$ (Johnson and Robb, 1973).

The mass loss of mixtures at different temperature ranges are given in Table 4, representing different reaction products as discussed above. In this study, the mass loss is divided into three groups and denoted as $\Delta \mathrm{m}_{1}, \Delta \mathrm{m}_{2}$ and $\Delta \mathrm{m}_{3}$ with the ranges of $50-200^{\circ} \mathrm{C}, 250-400^{\circ} \mathrm{C}$ and $400-800^{\circ} \mathrm{C}$ where $\mathrm{C}-(\mathrm{A})-\mathrm{S}-\mathrm{H}$; hydrotalcite; $\mathrm{CH}$ and $\mathrm{CO}_{3}{ }^{2-}$ containing phases decomposes, respectively. The maximum mass loss occurred between $50^{\circ} \mathrm{C}$ and $200^{\circ} \mathrm{C}\left(\triangle \mathrm{m}_{1}\right)$ for all mixes and mass change between these temperatures ranged between $9.9 \%$ and $23.9 \%$. Although the decomposition of other phases (dehydration of gaylussite and loss of interlayer water of hydrotalcite) overlaps with C-(A)-S-H within this range, their influence is supposed to be insignificant due to their relatively small amounts. Table 4 shows that the weight loss of C-(A)-S-H ranged between $9.9 \%$ and $14.9 \%$ for NC-6 and LNC-6 mixes and it gradually increased to $16.8 \%$ and $23.9 \%$ for $\mathrm{NC}-10$ and LNC-10 mixes. $\triangle \mathrm{m}_{1}$ increased with the increase in activator dosage, $\mathrm{NH}$ replacement and $\mathrm{CH}$ inclusion. Higher mass losses for this temperature range indicates a higher degree of reaction and this is consistent with the compressive strength results. This is expected that more slag particles are dissolved, consequently leads to a higher degree of the strength-giving phase formation. The mass loss between $250^{\circ} \mathrm{C}$ and $400^{\circ} \mathrm{C}\left(\triangle \mathrm{m}_{2}\right)$ slightly increased with the $\mathrm{NH}$ replacement, $\mathrm{CH}$ inclusion and higher activator dosage (Table 5). It was also observed that the value of $\Delta \mathrm{m}_{3}$ decreased with the $\mathrm{NH}$ replacement and increased with the higher activator dosage and $\mathrm{CH}$ inclusion, which means that the $\mathrm{CO}_{3}$ containing phases are more at these mixes. 
Table 5. Weight losses of mixtures (\%)

\begin{tabular}{lccc}
\hline Mixes & $\Delta \mathrm{m}_{1}$ & $\Delta \mathrm{m}_{2}$ & $\Delta \mathrm{m}_{3}$ \\
\hline NC100-6 & 9.9 & 1.6 & 5.2 \\
NC80-6 & 12.0 & 1.9 & 4.6 \\
NC60-6 & 13.7 & 1.9 & 2.6 \\
\hline LNC100-6 & 14.3 & 1.9 & 5.0 \\
LNC80-6 & 14.9 & 1.9 & 4.0 \\
LNC60-6 & 13.7 & 1.9 & 2.6 \\
\hline NC100-10 & 16.8 & 2.1 & 5.8 \\
NC80-10 & 23.9 & 2.6 & 5.0 \\
NC60-10 & 23.1 & 2.3 & 3.4 \\
\hline LNC100-10 & 17.6 & 2.2 & 5.9 \\
LNC80-10 & 23.1 & 2.6 & 5.4 \\
LNC60-10 & 22.4 & 3.0 & 4.9 \\
\hline
\end{tabular}

\section{CONCLUSIONS}

This experimental study has been performed to investigate the mechanisms that govern the strength development in sodium carbonate activated slags as a function of the nature of the alkaline activator. The purpose was to explore the strength gain mechanism of sodium carbonate activated slag mixes at room temperature curing. To enhance both early and ultimate compressive strength, different accelerators were used. Strength development mechanism has been clarified with the time dependent microstructure analysis. The study enables development of sustainable NC activated pozzolanic binders as feasible alternatives to OPC based systems.

The following conclusions can be drawn from this study:

- Activation of slag with only NC, exhibited hardly any strength ( 7 MPa) cured at room temperature up to 90 days.

- Addition of $\mathrm{NH}$ as a replacement of $\mathrm{NC}$ enhances the rate of dissolution of slag leading to a faster strength development. Although, replacement of $\mathrm{NC}$ with $\mathrm{NH}$ did not cause any considerable change in compressive strength at the early age for both activator dosages, significant increase was seen at further ages. 
- The presence of $\mathrm{CH}$ in the binder as a replacement of the slag led to a substantial increase in compressive strength irrespective of the $\mathrm{NH}$ usage and/or activator concentration. Enhanced strength development mainly caused by removing the carbonate from the medium and providing additional $\mathrm{Ca}^{2+}$ resources.

- Type and amount of accelerators and also activator dosage plays an important role in the strength development.

- Formation of the strength giving phases such as hydrotalcite and C-(A)-S-H plays an important role in strength development of NC activated slags.

- The detailed characterization of the microstructural development with the progress of hydration in mixes serve to an enhanced understanding of the strength development as a consequences of chemical changes.

A future perspective to the investigation can be in the form of a detailed study of the chemical reactions aided by molecular models that can effectively capture the hydration process of such alkali activated mixtures.

\section{Acknowledgements}

This work was supported by the research grant of Yildiz Technical University Research Foundation (Project No.: 2016-05-01-DOP03).

\section{REFERENCES}

Abdalqader, A. F., Jin, F., and Al-Tabbaa, A. (2015). “Characterisation of reactive magnesia and sodium carbonate-activated fly ash/slag paste blends." Constr. Build. Mater., 93, 506-513. https://doi.org/10.1016/j.conbuildmat.2015.06.015.

Abdalqader, A. F., Jin, F., and Al-Tabbaa, A. (2016). "Development of greener alkali-activated cement: Utilisation of sodium carbonate for activating slag and fly ash mixtures.” J. Clean. Prod., 113, 6675. https://doi.org/10.1016/j.jclepro.2015.12.010.

Al Bakri, A. M. M., Kamarudin, H., Bnhussain, M., Nizar, I. K., Rafiza, R. A., and Zarina. Y. (2011). "Microstructure of different $\mathrm{NaOH}$ molarity of fly ash-based green polymeric cement." J. Eng. Mater. Technol., 3(2), 44-49. 
ASTM (2016). "Standard test method for compressive strength of hydraulic cement mortars." C 109, ASTM, Philadelphia, Pa.

Atiş, C. D., Bilim, C., Çelik, Ö., and Karahan, O. (2009). "Influence of activator on the strength and drying shrinkage of alkali-activated slag mortar." Constr. Build. Mater., 23(1), 548-555. https://doi.org/10.1016/j.conbuildmat.2007.10.011.

Ben Haha, M., Le Saout, G., Winnefeld, F., and Lothenbach, B. (2011). "Influence of activator type on hydration kinetics, hydrate assemblage and microstructural development of alkali activated blastfurnace slags." Cem. Concr. Res., 41(3), 301-310. https://doi.org/10.1016/j.cemconres.2010.11.016.

Ben Haha, M., Lothenbach, B., Le Saout, G., and Winnefeld, F. (2012). "Influence of slag chemistry on the hydration of alkali-activated blast-furnace slag - Part II: Effect of $\mathrm{Al}_{2} \mathrm{O}_{3}$." Cem. Concr. Res., 41(9), 955-963. https://doi.org/10.1016/j.cemconres.2011.05.002.

Bernal, S. A., Provis, J. L., Myers, R., San Nicolas, J. R., and van Deventer, J. S. J. (2014). "Role of carbonates in the chemical evolution of sodium carbonate-activated slag binders." Mater. Struct. Constr., 48(3), 517-529. DOI:10.1617/s11527-014-0412-6.

Bernal, S. A., Provis, J. L., Rose, V., and Gutiérrez, R. M. (2013). "High-resolution X-ray diffraction and fluorescence microscopy characterization of alkali-activated slag-metakaolin binders." J. Am. Ceram. Soc., 96(6), 1951-1957. https://doi.org/10.1111/jace.12247.

Duxson, P., Provis, J. L., Lukey, G. C., and van Deventer, J. S. J. (2007). “The role of inorganic polymer technology in the development of green concrete." Cem. Concr. Res., 37(12), 1590-1597. https://doi.org/10.1016/j.cemconres.2007.08.018.

Dweck, J., Ferreira da Silva, P. F., Büchler, P. M., and Cartledge, F. K. (2002). "Study by thermogravimetry of the evolution of ettringite phase during type II Portland cement hydration." $J$. Therm. Anal. Calorim., 69(1), 179-186. DOI:10.1023/A:1019950126184.

Escalante-García, J. I., Fuentes, A. F., Gorokhovsky, A., Fraire-Luna, P. E., and Mendoza-Suarez, G. (2003). "Hydration products and reactivity of blast-furnace slag activated by various alkalis." J. Am. Ceram. Soc., 86(12), 2148-2153. https://doi.org/10.1111/j.1151-2916.2003.tb03623.x.

Fernandez-Jimenez A. and Puertas, F. (2001). "Setting of alkali-activated slag cement. Influence of activator nature.” Adv. Cem. Res., 13(3), 115-121. DOI:10.1680/adcr.13.3.115.39288. 
Gebregziabiher, B.S., Thomas, R., and Peethamparan, S. (2015). "Very early-age reaction kinetics and microstructural development in alkali-activated slag." Cem. Concr. Compos., 55, 91-102. https://doi.org/10.1016/j.cemconcomp.2014.09.001.

Gu, K., Jin, F., Al-Tabbaa, A., Shi, B., and Liu, J., (2014). "Mechanical and hydration properties of ground granulated blastfurnace slag pastes activated with $\mathrm{MgO}-\mathrm{CaO}$ mixtures." Constr. Build. Mater., 69, 101-108. https://doi.org/10.1016/j.conbuildmat.2014.07.032.

Huanhani, Z., Xuequan, W., Zhongzi, X., and Mingshu, T. (1993). "Kinetic study on hydration of alkaliactivated slag." Cem. Concr. Res., 23(6), 1253-1258. https://doi.org/10.1016/0008-8846(93)90062E.

Jeon, D., Jun, Y., Jeong, Y., and Oh, J. E. (2015). "Microstructural and strength improvements through the use of $\mathrm{Na}_{2} \mathrm{CO}_{3}$ in a cementless $\mathrm{Ca}(\mathrm{OH})_{2}$-activated Class $\mathrm{F}$ fly ash system." Cem. Concr. Res., 67, 215-225. https://doi.org/10.1016/j.cemconres.2014.10.001.

Jeong, Y., Jae, E. O., Jun, Y., Park, J., Ha, J., and Sohn, S. G., (2015). "Influence of four additional activators on hydrated-lime $\left[\mathrm{Ca}(\mathrm{OH})_{2}\right]$ activated ground granulated blast-furnace slag." Cem. Concr. Compos., 65, 1-10. https://doi.org/10.1016/j.cemconcomp.2015.10.007.

Jin, F., Gu, K., and Al-Tabbaa, A., (2015). "Strength and hydration properties of reactive MgO-activated ground granulated blastfurnace slag paste." Cem. Concr. Compos., 57, 8-16. https://doi.org/10.1016/j.cemconcomp.2014.10.007.

Johnson D. R. and Robb, W. A. (1973). "Gaylussite: Thermal properties by simultaneous thermal analysis. Am. Mineral., 58, 778-784.

Ke, X., Bernal, S. A., and Provis, J. L. (2016). "Controlling the reaction kinetics of sodium carbonateactivated slag cements using calcined layered double hydroxides." Cem. Concr. Res., 81, 24-37. https://doi.org/10.1016/j.cemconres.2015.11.012.

Kim, M. S., Jun, Y., Lee, C., and Oh, J. E. (2013). "Use of CaO as an activator for producing a pricecompetitive non-cement structural binder using ground granulated blast furnace slag." Cem. Concr. Res., 54, 208-214. https://doi.org/10.1016/j.cemconres.2013.09.011. 
Kovtun, M., Kearsley, E. P., and Shekhovtsova, J. (2015). "Chemical acceleration of a neutral granulated blast-furnace slag activated by sodium carbonate." Cem. Concr. Res., 72, 1-9. https://doi.org/10.1016/j.cemconres.2015.02.014.

Li, Y. and Sun, Y. (2000). "Preliminary study on combined-alkali-slag paste materials." Cem. Concr. Res., 30(6), 963-966. https://doi.org/10.1016/S0008-8846(00)00269-6.

Lloyd, R. R., Provis, J. L., and van Deventer, J. S. J. (2010). "Pore solution composition and alkali diffusion in inorganic polymer cement." Cem. Concr. Res., 40(9), 1386-1392. https://doi.org/10.1016/j.cemconres.2010.04.008.

Luukkonen, T., Abdollahnejad, Z., Yliniemi, J., Kinnunen, P., and Illikainen, M. (2018). "One-part alkali-activated materials: A review." Cem. Concr. Res., 103, 21-34. https://doi.org/10.1016/j.cemconres.2017.10.001.

Marcu, A., Stoefs, W., Belis, D., and Tuokko, K. (2015). Sectoral case study-soda ash climate for sustainable growth.

Martinez-Lopez, R. and Escalante-Garcia, J. I. (2016). "Alkali activated composite binders of waste silica soda lime glass and blast furnace slag: Strength as a function of the composition." Constr. Build. Mater., 119, 119-129. https://doi.org/10.1016/j.conbuildmat.2016.05.064.

Parashar, P., Sharma, V., Agarwal, D. D., and Richhariya, N. (2012). "Rapid synthesis of hydrotalcite with high antacid activity." Mater. Lett., 74, 93-95. https://doi.org/10.1016/j.matlet.2011.12.115.

Provis, J. L. and van Deventer, J. S. J. (2014). "Alkali Activated Materials State-of-the-Art Report" RILEM TC 224-AAM. DOI:10.1007/978-94-007-7672-2.

Provis, J. L. (2014). “Geopolymers and other alkali activated materials: Why, how, and what?.” Mater. Struct. Constr., 47(1-2), 11-25. DOI:10.1617/s11527-013-0211-5.

Puertas, A. and Fernandez Jimenez, F. (2003). "Mineralogical and microstructural characterisation of alkali-activated fly ash/slag pastes." Cem. Concr. Compos., 25(3), 287-292. https://doi.org/10.1016/S0958-9465(02)00059-8.

Puertas, A., Martínez-Ramírez, S., Alonso, S., and Vázquez, T. (2002). “Alkali-activated fly ash/slag cements: Strength behaviour and hydration products." Cem. Concr. Res., 30(10), 1625-1632. https://doi.org/10.1016/S0008-8846(00)00298-2. 
Puertas, F. and Torres-Carrasco, M. (2014). "Use of glass waste as an activator in the preparation of alkali-activated slag. Mechanical strength and paste characterisation." Cem. Concr. Res., 57, 95-104. https://doi.org/10.1016/j.cemconres.2013.12.005.

Rashad, A. M., Zeedan, S. R., and Hassan, A. A. (2016). "Influence of the activator concentration of sodium silicate on the thermal properties of alkali-activated slag pastes." Constr. Build. Mater., 102(1), 811-820. https://doi.org/10.1016/j.conbuildmat.2015.11.023.

Richardson, J. M., Biernacki, J. J., Stutzman, P. E., and Bentz, D. P. (2010). "Stoichiometry of slag hydration with calcium cydroxide." J. Am. Ceram. Soc., 85(4), 947-953. DOI:10.1111/j.11512916.2002.tb00197.x.

Scrivener, K. L. and Kirkpatrick, R. J. (2008). "Innovation in use and research on cementitious material." Cem. Concr. Res. 38(2), 128-136. https://doi.org/10.1016/j.cemconres.2007.09.025.

Shi, C. and Day, R. L. (2000). "Pozzolanic reaction in the presence of chemical activators." Cem. Concr. Res., 30(4), 607-613. https://doi.org/10.1016/S0008-8846(99)00205-7.

Shi, C., Krivenko, P. V., and Della, R. (2006). Alkali-Activated Cements and Concretes. https://doi.org/10.1201/9781482266900.

Sikander, U., Sufian, S., and Salam, M. A. (2017). "A review of hydrotalcite based catalysts for hydrogen production systems." Int. J. Hydrogen Energy, 42(31), 19851-19868. https://doi.org/10.1016/j.ijhydene.2017.06.089.

Temuujin, J., van Riessen, A., and Williams, R. (2009). "Influence of calcium compounds on the mechanical properties of fly ash geopolymer pastes." J. Hazard. Mater., 167(1-3), 82-88. https://doi.org/10.1016/j.jhazmat.2008.12.121.

Turner, L. K. and Collins, F. G. (2013). "Carbon dioxide equivalent $\left(\mathrm{CO}_{2}-\mathrm{e}\right)$ emissions: A comparison between geopolymer and OPC cement concrete." Constr. Build. Mater., 43, 125-130. https://doi.org/10.1016/j.conbuildmat.2013.01.023.

van Deventer, J. S. J., Provis, J. L., Duxson, P., and Brice, D. G. (2010). "Chemical research and climate change as drivers in the commercial adoption of alkali activated materials." Waste Biomass Valorization. 1(1), 145-155. DOI:10.1007/s12649-010-9015-9. 
Wang, J., Lyu, X. J., Wang, L., Cao, X., Liu, Q., and Zang, H. (2018). "Influence of the combination of calcium oxide and sodium carbonate on the hydration reactivity of alkali-activated slag binders." $J$. Clean. Prod., 171, 622-629. https://doi.org/10.1016/j.jclepro.2017.10.077.

Wang, S. D. and Scrivener, K. L. (2003). “29 Si and ${ }^{27} \mathrm{Al}$ NMR study of alkali-activated slag.” Cem. Concr. Res., 33(5), 769-774. https://doi.org/10.1016/S0008-8846(02)01044-X.

Winnefeld, F., Ben Haha, M., Le Saout, G., Costoya, M., Ko, S.C., and Lothenbach, B. (2014). "Influence of slag composition on the hydration of alkali-activated slags." J. Sustain. Cem. Mater., 4(2), 85-100. https://doi.org/10.1080/21650373.2014.955550.

Yang, K. H., Song, J. K., and Song, K. (2013). “Assessment of $\mathrm{CO}_{2}$ reduction of alkali-activated concrete." J. Clean. Prod., 39, 265-272. https://doi.org/10.1016/j.jclepro.2012.08.001.

Yuan, B., Straub, C., Segers, S., Yu, Q. L., and Brouwers, H. J. H., (2017). "Sodium carbonate activated slag as cement replacement in autoclaved aerated concrete." Ceram. Int., 43(8), 6039-6047. https://doi.org/10.1016/j.ceramint.2017.01.144.

Yusuf, M. O., Johari, M. A. M., Ahmad, Z. A., and Maslehuddin, M. (2014). "Effects of addition of $\mathrm{Al}(\mathrm{OH})_{3}$ on the strength of alkaline activated ground blast furnace slag-ultrafine palm oil fuel ash (AAGU) based binder." Constr. Build. Mater., 50, 361-367. https://doi.org/10.1016/j.conbuildmat.2013.09.054. 